\title{
ON THE SPECIFIC STATE OF CRUSTAL STRESSES IN INTRACONTINENTAL OROGENS
}

\author{
Yu. L. Rebetsky \\ O.Yu. Schmidt Institute of Physics of the Earth RAS, Moscow, Russia
}

\begin{abstract}
The article presents a systematic review of the available tectonophysical data on the state of crustal uplifts and basins in intracontinental orogens. Based on results of the tectonophysical analysis of data on earthquake focal mechanisms for the Altai-Sayan and Northern Tien Shan regions, it is established that in many cases the crust in the basins and uplifts has antipodal structures, considering various types of the state of stresses. In the crust of the uplifts, maximum compression axes are usually sub-horizontal; in the crust of the basins, only the axis of the principal stress of minimum compression (i.e. maximum deviatoric extension) is sub-horizontal. These observations correlate well with estimations of deformations on the surface of the crust on the basis of the GPS-geodesy data, as well as with stress measurements taken directly on mining sites. The antipodal structures and physical fields in the crust of the uplifts and basins are not a random phenomenon. This suggests a common mechanism of deformation at the stage of active formation of the uplifts and basins.

However, results of a similar tectonophysical analysis performed for the crust of the Pamir plateau and Tibet show that minimum compression stresses are sub-horizontal in these regions, and the geodynamic type of the state of stresses is determined as horizontal extension or horizontal shearing. This pattern contrasts sharply with the type of the state of stresses of horizontal compression in the crust of the mountain ranges around the plateau (the Himalayas, Kunlun, Tsilian Shan, Hindu Kush), as well as with the state of stresses of active orogenic structures of the Tien Shan and Altai-Sayan regions.

Based on the stress values estimated for a range of geodynamic types of the state of stresses, it is estimated that additional compression stresses of the order of $5.4 \mathrm{kbar}$ are required for the transition from horizontal extension to horizontal compression. If the regional strain rates currently recorded by the GPS-geodesy are taken into account, such additional stresses need to be applied for about 10 million years to fulfill the transition.
\end{abstract}

Key words: stress; strain; deformation; fractures; joint; mountain uplift; basin; plateau

Recommended by V.G. Trifonov

For citation: Rebetsky Yu.L. 2015. On the specific state of crustal stresses in intracontinental orogens. Geodynamics \& Tectonophysics 6 (4), 437-466. doi:10.5800/GT-2015-6-4-0189.

Для цитирования: Ребецкий Ю.Л. Об особенности напряженного состояния коры внутриконтинентальных орогенов // Геодинамика и тектонофизика. 2015. Т. 6. № 4. С. 437-466. doi:10.5800/GT2015-6-4-0189.

\section{ОБ ОСОБЕННОСТИ НАПРЯЖЕННОГО СОСТОЯНИЯ КОРЫ ВНУТРИКОНТИНЕНТАЛЬНЫХ ОРОГЕНОВ}

\section{Ю. Л. Ребецкий}

Институт физики Земли им. О.Ю. Шмидта РАН, Москва, Россия 


\begin{abstract}
Аннотация: Проведена систематизация существующих тектонофизических данных о состоянии коры поднятий и впадин внутриконтинентальных орогенов. Результаты тектонофизического анализа данных о механизмах очагов землетрясений для Алтае-Саян и Северного Тянь-Шаня позволили выявить, что кора впадин и поднятий в большом числе случаев выглядит как антиподная структура по режиму напряженного состояния. В коре поднятий, как правило, оси максимального сжатия субгоризонтальны, а в коре прогибов субгоризонтальна ось главного напряжения минимального сжатия (максимального девиаторного растяжения). Эти данные хорошо коррелируют с результатами расчетов деформаций на поверхности коры, полученными GPSгеодезией, и с данными по замерам напряжений методами in-situ в горном деле. Такая антиподность строения и физических полей коры впадин и поднятий не случайна и говорит о едином механизме деформирования на стадии их активного развития.

Вместе с тем по результатам такого же тектонофизического анализа, выполненного для коры плато Памира и Тибета, установлено, что здесь в субгоризонтальном направлении действуют напряжения минимального сжатия, что определяет геодинамический тип напряженного состояния в виде горизонтального растяжения или горизонтального сдвига. Подобная закономерность резко контрастирует с типом напряженного состояния горизонтального сжатия в коре поднятий в виде хребтов, окружающих эти плато (Гималаи, Куньлунь, Цилиан-Шань, Гиндукуш), а также с характером напряженного состояния активных орогенных структур Тянь-Шаня и Алтае-Саян.

Выполненные оценки величин напряжений, отвечающие различным геодинамическим типам напряженного состояния, показывают, что переход от режима горизонтального растяжения к горизонтальному сжатию требует приложения дополнительных сжимающих напряжений порядка 5.4 кбар, что может занять около 10 млн лет при наблюдаемых в настоящее время с помощью GPS-геодезии скоростях региональных деформаций.
\end{abstract}

Ключевые слова: напряжение; деформация; разрыв; трещина; горное поднятие; впадина; горное плато

\section{1. ВВЕДЕНИЕ}

Целью настоящей работы является изучение механизмов генерации напряжений, действующих в континентальной коре в областях орогенов. По определению М.В. Гзовского [Gzovsky, 1975], выяснение параметров напряженного состояния и механизмов их генерации в коре является основной обратной задачей тектонофизики. Наряду с этим, установление условий нагружения и деформирования литосферы внутриконтинентальных орогенов, определяющих особенности морфологического строения и физических свойств пород коры горно-складчатых областей, является обратной задачей геодинамики [Leonov, 1995, 2009], тектонофизика при этом рассматривается как важнейший инструмент исследований.

При решении таких обратных задач используются методы физического [Gzovsky, 1954a, 1954b, 1963; Osokina, 1963; Geptner, 1970; Mikhailova, 1971; Stoyanov, 1979; Bondarenko, Luchitsky, 1985; Bornyakov, 1988; Seminsky, 1991] и математического [Grigoriev, Mikhailova, 1985; Grigoriev et al., 1989; Grigoriev, 1991; Rebetsky, 1988; Rebetsky, Mikhailova, 2014; Stefanov et al., 2009] моделирования, на основе которых делаются выводы о соответствии принятых в моделях краевых условий нагружения природному объекту.
Однако практика показывает, что решение подобных обратных задач геодинамики не единственное и результат зависит от широты спектра параметров, по которым выполняется сопоставление природного объекта с моделью. Чем уже спектр сравниваемых параметров, тем больше вариантов нагружения модели позволят получить значения этих параметров, близкие к природным. Т.е. разные модели среды и модели нагружения могут давать результаты, удовлетворяющие природному объекту, в рамках каких-то сравниваемых параметров. Увеличивая спектр сопоставляемых параметров, можно уменьшить число модельных вариантов условий нагружения и свойств геологического объекта, дающих результаты, близкие к природному объекту.

Достаточно часто сопоставление природного объекта и модели ограничено данными о кинематике поверхности коры и рельефе основных ее слоев, а также о геометрии глубинных областей разрушения - зон повышенной сейсмичности. На примере конкретных работ по моделированию зон субдукции [Guterman, 1987; Demin, Nikitin, 1991; Maslov, Komova, 1990], выполненных с разных научных позиций, можно показать, что этих данных недостаточно для получения единственного решения задачи. Существенно сужает неединственность подбора условий нагружения привлечение данных о природном 
напряженном состоянии, которые могут быть получены в результате тектонофизического анализа совокупностей сейсмологических (механизмы очагов землетрясений) или геологических (зеркала скольжения) индикаторов о разрывных смещениях (обзоры этих методов представлены в работах [Sherman, Dneprovsky, 1989; Rebetsky, 2003, 2007]). Несмотря на то, что подобные данные невозможно получить для всего исследуемого трехмерного участка коры, а также на то, что эти напряжения всегда являются средними для некоторых частей его объема, именно данные о напряженном состоянии коры следует рассматривать как критически необходимые при решении подобных задач.

Отправной точкой настоящих исследований являются результаты тектонофизической реконструкции природных напряжений, выполненные с применением метода катакластического анализа [Rebetsky, 1997, 2007], которые ранее были получены в совместных исследованиях с О.А. Кучай (ИНГГ СО РАН, г. Новосибирск) и Н.А. Сычевой (НС РАН, г. Бишкек) [Rebetsky, 2008a, 2008b; Rebetsky et al., $2007,2009,2010,2012,2013]$, для коры двух центральноазиатских орогенов: Алтае-Саян (AC) и Северного Тянь-Шаня (СТШ). Продолжением этих работ также являлись исследования современного напряженного состояния коры Тибета, Памира и Гималаев - Высокая Азия (BА) [Rebetsky, Alekseev, 2014]. Анализ данных о природных напряжениях этих регионов позволил выявить ряд важных закономерностей их пространственного распределения, которые не укладывались в простую схему латерального сжатия как единственно «верного» механизма, ответственного за горообразование.

На рис. 1 показаны районы исследований напряженно-деформированного состояния коры, выполненные как по нашим собственным данным, так и по данным других авторов. Особо следует отметить, что использованы различные подходы в изучении напряженно-деформированного состояния коры.

Нами рассматривалось состояние коры не только для горных поднятий, но и для сочленяющихся с ними участков пониженного рельефа - прогибов коры. При этом для участков прогибов будем, вслед за В.И. Макаровым [Makarov, 1977, 1980; Makarov et al., 2010, 2011], выделять внутригорные впадины, захватывающиеся в процесс общего поднятия орогенических структур, а также межгорные впадины: котловины, депрессии и предгорные прогибы. Эти разные по характеру и масштабам структуры (поднятия и впадины) длительное время развиваются параллельно и каким-то образом сосуществуют. Будем также различать горные поднятия, имеющие форму хребтов (резко выраженный градиент поверхности), и поднятия в виде нагорья и плато (плоская форма).

\section{2. НАПРЯЖЕНИЯ ВЕРХНИХ СЛОЕВ КОРЫ ПО ДАННЫМ ГОРНОЙ МЕХАНИКИ}

Измерения природных напряжений в массивах пород, выполненные в горном деле (in-situ методы, в основном методы разгрузки и гидравлического разрыва скважин [Peive, Kropotkin, 1973; Turchaninov, 1982]), показывают определенную взаимосвязь геодинамического режима напряженного состояния с направленностью вертикальных движений. Так, согласно работе [Markov, 1977], в зонах прогибов и на участках медленных погружений поверхности чехла платформ горизонтальные сжимающие напряжения $\sigma_{x}$ и $\sigma_{y}$ в основном (около $75 \%$ от общего числа замеров) меньше вертикальных (рис. 2, б). В скальных породах кристаллического и складчатого фундамента земной коры, выведенных ближе к поверхности вертикальными тектоническими движениями, и для щитов [Markov, 1980; Kurlenya, 1996] напряжения горизонтального сжатия обычно превосходят (около 60 \%) вертикальные сжимающие напряжения (рис. 2,a). Установлено, что, несмотря на широкий диапазон изменений напряжений, действующих в горизонтальном направлении, напряжения в вертикальном направлении близки к значению литостатического давления.

Превышение горизонтального сжатия над вертикальным напряжением может быть 5-10-кратное (на Хибинских рудниках такое превышение в некоторых случаях 20-кратное [Markov, 1972, 1977]). В работе [Markov, 1985] Хибинский и Ловоозерский массивы Кольского полуострова приводятся в качестве наиболее ярких примеров приуроченности режимов горизонтального сжатия к областям восходящих движений земной коры. Подобные движения эти массивы испытывали в прошлом и в настоящем. Г.А. Марков в работе [Markov, 1985] особо обращал внимание на тот факт, что в областях с восходящими движениями активно идут денудационные процессы, поэтому он связывал повышенные значения напряжений горизонтального сжатия с остаточными напряжениями, формирующимися как результат упругой разгрузки пород, вызванной денудационными процессами [Voigth, 1966; Voight, Pierre, 1974]. В массивах, не испытывающих в настоящее время активных тектонических поднятий, подобный тип геодинамического режима менее распространен. Отметим, что замеры напряжений in-situ методами относятся к самой верхней части коры и отвечают глубинам 1-3 км.

Отмечая особенности формирования режима горизонтального сжатия, Г.А. Марков [Markov, 1977, 1985] обращает внимание на тот факт, что наиболее высокие уровни этих напряжений наблюдаются на небольших глубинах, чуть ниже уровня дна 


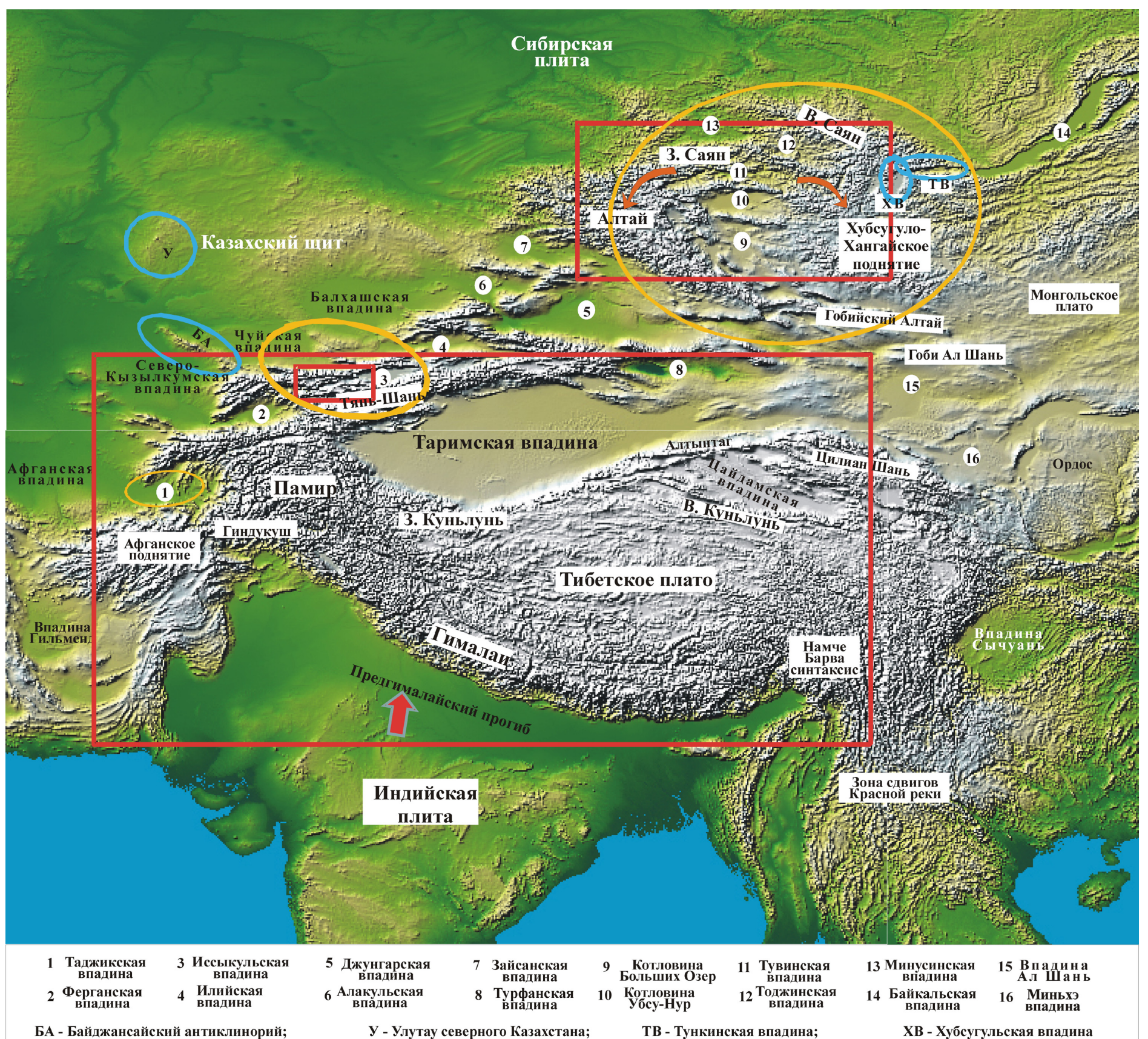

Рис. 1. Внутриконтинентальные орогены, крупные внутригорные впадины, межгорные впадины и передовые прогибы Центральной и Юго-Восточной Азии с элементами геодинамики литосферных плит.

Прямая красная стрелка с азимутом 20-22 показывает направление движения Индийской плиты относительно стабильной Евразии по данным GPS-геодезии [Zubovich et al., 2007], а закругленные оранжевые стрелки отражают представления о повороте Северо-Восточного Алтая против часовой стрелки согласно работе [Novikov, 2004]. Цветовая гамма отражает различие в высотах рельефа (для континента от темно-зеленого через желтый к светло-серому). Красными прямоугольниками и светло-синими эллипсами выделены области, исследование напряженного состоянии которых выполнялось тектонофизическими методами, соответственно по сейсмологическим данным о механизмах очагов землетрясений и по данным о зеркалах скольжения (палеонапряжения). Темно-желтыми эллипсами выделены участки коры, для которых на основе геофизических методов (космическая геодезия GPS) определены латеральные деформации поверхности.

Fig. 1. Intracontinental orogenes, large intra- and intermountain basins and foretroughs of Central and Southeast Asia, with lithospheric plate geodynamics elements.

The red arrow with azimuth $20-22^{\circ}$ shows the direction of movement of the Indian plate with respect to the relatively stable Eurasian plate according the GPS-geodesy data [Zubovich et al., 2007]. The counterclockwise rotation of the North-Eastern Altai, which is assumed according to [Novikov, 2004], is shown by orange arrows. Different elevations are colour coded (for the continent, from dark green trough yellow to light gray). Red boxes and light-blue ellipses mark areas where the state of stresses was studied by tectonophysical methods, respectively, on the basis of seismological data on earthquake focal mechanisms and the slickenside (paleostress) data. Dark yellow ellipses show areas of the crust with lateral deformations of the surface which are revealed by geophysical techniques, including GPS-geodesy. 

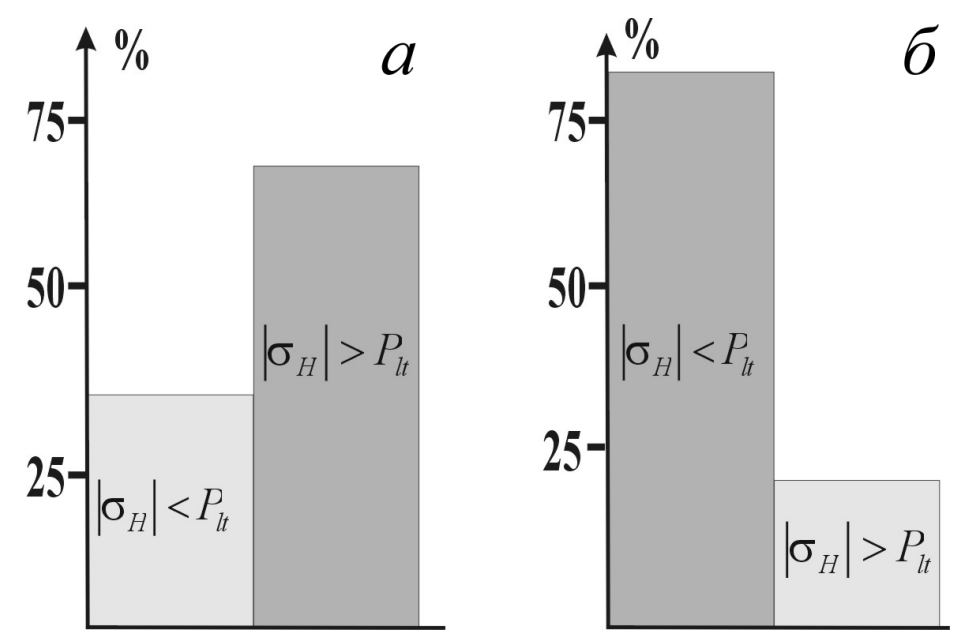

Рис. 2. Соотношение числа определений в \% с разным значением отношения средних горизонтальных $\sigma_{H}=$ $=0.5\left(\sigma_{x}+\sigma_{y}\right)<0$ (сжимающие напряжения имеют отрицательные значения) и вертикальных $\sigma_{z}=-P_{l t}\left(P_{l t}-л и-\right.$ тостатическое давление) напряжений: $a-\left|\sigma_{H}\right|>P_{l t}$ имеет преимущественное распределение для складчатого и кристаллического фундамента, горных поднятий; $\sigma-\left|\sigma_{H}\right|<P_{l t}$ имеет преимущественное представительство для плит, чехла платформ и впадин. Рисунок из работы [Markov, 1977] с дополнениями.

Fig. 2. The percentage of the number of estimations with different ratios of the average horizontal $\sigma_{H}=0.5\left(\sigma_{x}+\sigma_{y}\right)<0$ (compression stresses are negative) and vertical $\sigma_{z}=-P_{l t}\left(P_{l t}\right.$ is lithostatic pressure) stresses: $a-\left|\sigma_{H}\right|>P_{l t}$ dominates for the folded and crystalline basements and mountain uplifts; $\sigma-\left|\sigma_{H}\right|<P_{l t}$ b dominates for the plates and the platforms' and basins' cover. The figure is from [Markov, 1977] with additions.

межгорных долин. Породы в вершинах гор, расположенные выше местных базисов эрозии, в большей части разгружены от действия повышенных (надлитостатических) горизонтальных сжимающих напряжений.

Данные in-situ измерений показывают, что вертикальные напряжения близки к значениям, отвечающим литостатическому давлению (рис. $3, a$ ). Установлено, что с глубиной возможно изменение геодинамического режима после выравнивания горизонтальных и вертикальных напряжений (рис. 3, б). На больших глубинах диапазон изменения напряжений горизонтального сжатия составляет от 0.3 до 0.8-1.0 от величины литостатического давления. Из данных рис. 3,6 , также следует, что с глубиной уменьшается число замеров напряжений, для которых горизонтальное сжатие преобладает над вертикальным сжатием. Количество участков с замерами напряжений, отвечающих изотропному распределению напряжений (рис. 3, 6, вертикальный столбец вблизи $k=1$ ), когда вертикальные и горизонтальные напряжения близки к литостатике [Hеim, 1878], составляет существенно меньшую часть от общего числа замеров со стандартным напряженным состоянием или состоянием с обнаруживаемым проявлением тектонических напряжений.

В скальных массивах горно-складчатых сооружений наблюдается периодическая пространствен- ная изменчивость режимов напряженного состояния, когда в соседних областях поднятия и опускания режимы напряженного состояния резко контрастны. Наибольшее проявление такой изменчивости режимов напряженного состояния приурочено к зонам контакта горных областей с геоструктурами платформ.

Для всех глубин измерений напряжений минимальное значение горизонтального сжатия составляет около 0.3 от литостатического давления, что соответствует значению латеральных напряжений для упругой реакции среды на литостатическую нагрузку для значений коэффициента Пуассона 0.25 [Dinnik, 1926]. Отсутствие замеров с меньшим уровнем напряжений говорит о том, что в участках замеров не происходит абсолютное латеральное расширение, способное уменьшить боковую стесненность деформирования для чисто гравитационного напряженного состояния.

Следует заметить, что в горном деле стандартным напряженным состоянием, отвечающим действию только гравитационных сил, является напряженное состояние с субвертикальной ориентацией осей максимального сжатия. В этом случае вертикальные напряжения определяются весом вышележащих пород, а горизонтальные рассчитываются из условия отсутствия в этом направлении деформаций (полное боковое стеснение). Подобный тип напряженного состояния для чисто упру- 


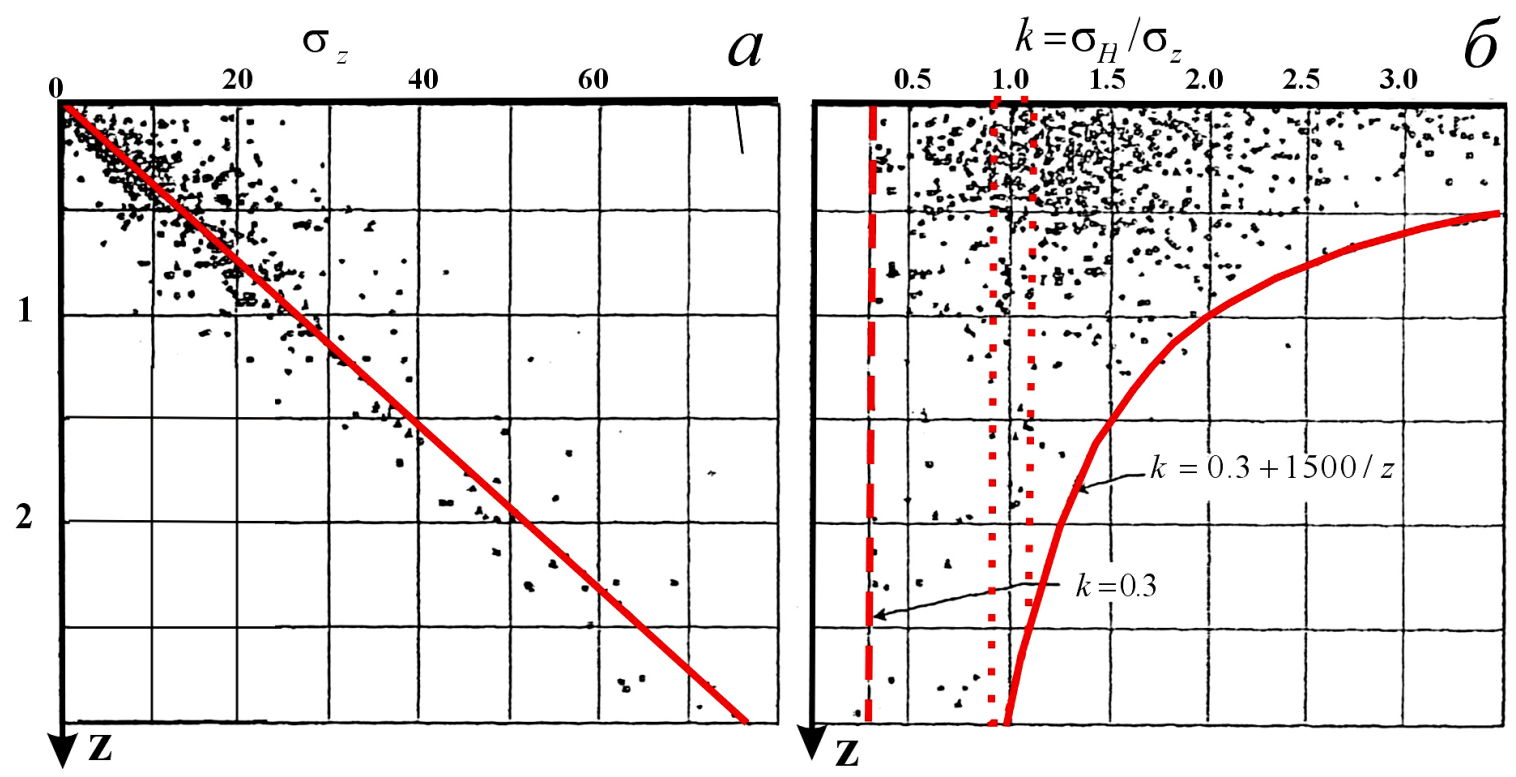

Рис. 3. Распределение по глубине: $a$ - вертикальных напряжений $\sigma_{z}$ (красная линия отвечает $\left.\sigma_{z}=-P_{l t}\right)$; $\sigma-$ отношения полусуммы горизонтальных напряжений к вертикальным $k=\sigma_{H} / \sigma_{z}$ (красный пунктир отвечает уровню упругого состояния, красная линия - граница максимальных значений $k$ для данной глубины, колонка точечного пунктира показывает области изотропного напряженного состояния $\sigma_{H} \approx \sigma_{z}$ ). Рисунок из работы [Brady, Brown, 2004] с дополнениями.

Fig. 3. Depth patterns: $a$ - vertical stresses $\sigma_{z}$ (the red line refers to $\sigma_{z}=-P_{l t}$ ); $\sigma$ - the ratio of the half-sum of horizontal stresses to vertical stresses $k=\sigma_{H} / \sigma_{z}$ (the red dashed line shows the level of elastic state; the red line shows the boundary of maximum values of $k$ for the specified depth; the column of the dotted line shows areas of isotropic stress state $\sigma_{H} \approx \sigma_{z}$ ). The figure is from [Brady, Brown, 2004] with additions.

гой, упруговязкой или упругопластической реакции геосреды рассматривался в работах [Dinnik, 1926; Tsimbarevich, 1948; Liberman, 1962; Krupennikov et al., 1972; Jager, 1972]. Так, для чисто упругой реакции пород (верхние горизонты осадочных бассейнов - первые сотни метров и блоков кристаллической коры - 1-2 км) и стандартного значения коэффициента Пуассона 0.25 величина напряжений горизонтального сжатия должна быть втрое меньше литостатического давления. Отклонение природного напряженного состояния от теоретически предсказываемого в горно-инженерном деле, когда напряжения горизонтального сжатия превышают литостатическое давление, связывают с действием тектонических напряжений [Gzovsky, 1954a, 1954b]. Использование подобного термина определяет предполагаемую взаимосвязь наблюдаемых напряжений с влиянием сил (напряжений) от удаленных границ тектонических плит [Kozyrev, Savchenko, 2000; и др.].

В работах [Rebetsky, 2008a, 2008b, 2008c] было показано, что в областях поднятий, сопровождающихся денудацией поверхности, повышенные значения горизонтального сжатия относительно стандартного состояния (вплоть до аномально больших, многократно превышающих литостатическое давление пород) могут определяться не дальнодействующими силами, а остаточными напряжениями гравитационного напряженного состояния. В этих исследованиях был разработан математический аппарат, позволяющий связывать величины формирующихся остаточных напряжений с амплитудами денудации воздымающейся поверхности и параметрами прочности горных пород.

Следует заметить, что В.С. Пономарев [Ропота$r e v, 2007,2008]$ в своих исследованиях также отмечает специфическую роль денудации поверхности коры, испытывающей воздымание. Здесь говорится о неких латентных (скрытых) напряжениях, остающихся в среде после денудационной разгрузки. Но в работах В.С. Пономарева, так же как и в работах Г.А. Маркова, нет формального описания явления, в них не получено соотношений, позволяющих говорить об уровне этих остаточных напряжений. Теоретические аспекты проблемы рассматривались в работах [Goodman, 1989; Rebetsky, 2008a, 2008b, 2008c; Rebetskii, 2011].

Вероятно, впервые о необходимости учета остаточных напряжений гравитационного напряженного состояния, формирующихся в коре областей поднятий в результате денудации поверхности, было сказано Б. Войгхтом [Voight, 1966]. Позднее в 

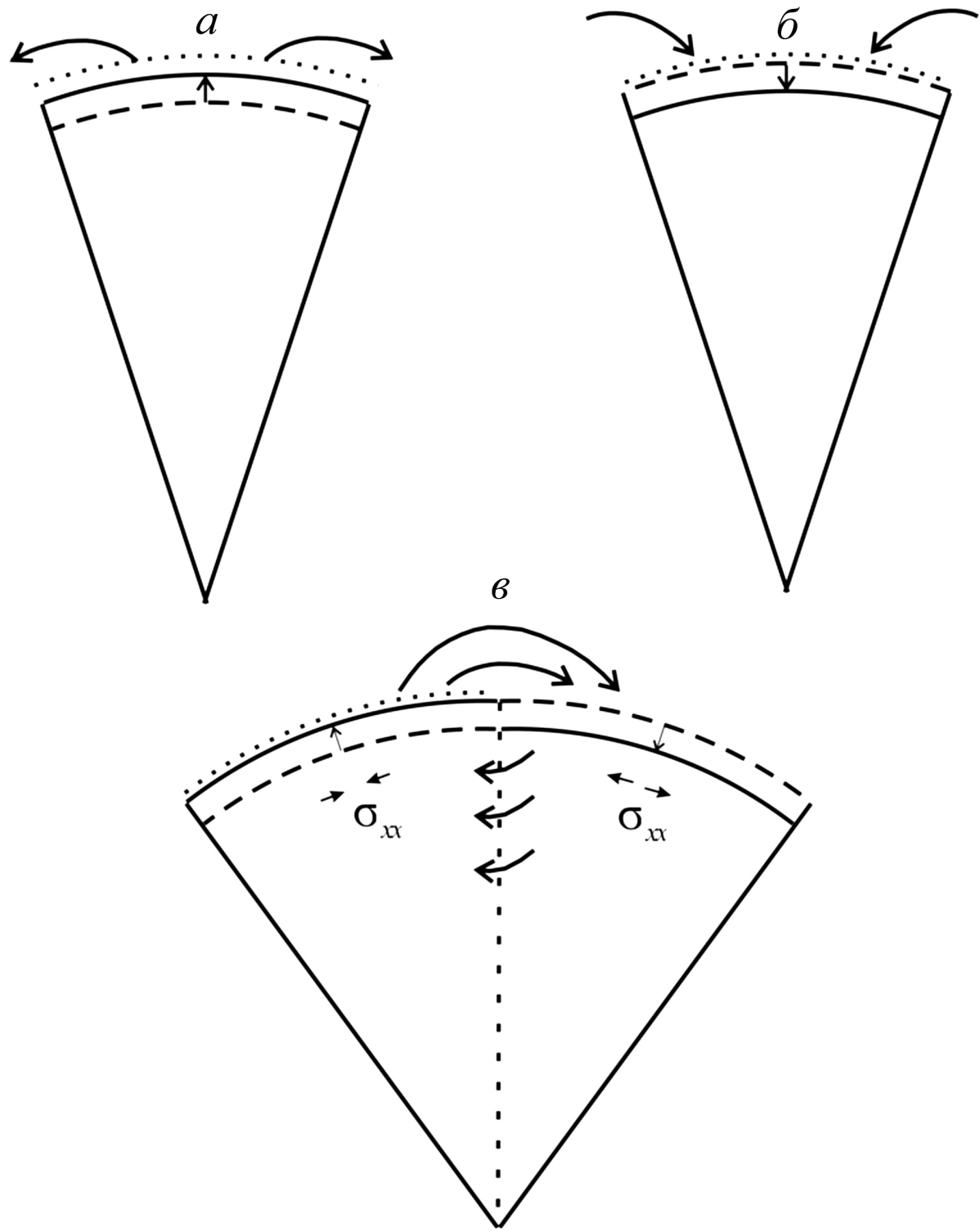

Рис. 4. Схемы изменения геометрии приповерхностных слоев на сферической Земле отдельно для поднятий (a) и для впадин (б), соответственно по Д. Тёркотту [Turcotte, 1974] и по А.В. Магницкому [Magnitsky, 1965] (пояснение в тексте), а также для объединенных в единую ячейку участков поднятия и прогиба коры $(8)$.

Стрелки на поверхности показывают направление переноса вещества в процессе денудации поднятий $(a)$ и осадконакопления в осадочных бассейнах (б). Вертикальная пунктирная линия и пересекающие ее стрелки показывают, что граница между областями поднятия и прогиба условная, здесь имеет место внутрикоровое перетекание вещества.

Fig. 4. Schemes showing changes in the geometry of the surface layers on the spherical Earth: (a) uplifts [Turcotte, 1974]; (б) basins [Magnitsky, 1965] (see explanations in the text); ( 8 ) areas of crust uplifts and troughs (in a single cell).

Arrows on the surface show directions of the material transfer during denudation of uplifts $(a)$ and sedimentation in sedimentary basins $(8)$. The vertical dashed line and arrows across the line show that the boundary between the uplift and trough areas is conditional, and the intra-crustal flow of material takes place there.

работах Д. Тёркотта [Turcotte, 1974; Haxby, Turcotte, 1976] был сделан ошибочный вывод о компенсации этих остаточных деформаций за счет сферичности планеты. Аналогично с позиции влияния сферичности в работах [Kosygin, Magnitsky, 1948; Magnitsky, 1965] рассматривался вопрос возникновения дополнительного сжатия в областях прогибов.
Однако эти структуры формируются совместно (правило Карпинского), и в этом случае влияние сферичности в области активно развивающихся поднятия и впадины взаимно компенсируется (рис. 4). Поэтому при прогнозе состояния впадин и поднятий их нельзя рассматривать отдельно друг от друга. 
Комментируя рис. 4, следует отметить, что показанные на нем стрелочки сжатия (кора поднятия) и растяжения (кора впадины) не обязательно соответствуют ориентации максимального сжимающего $\sigma_{3}$ и максимального растягивающего $\sigma_{1}$ девиаторного напряжения (здесь и далее знак нормальных напряжений соответствует принятому в классической механике - растяжение положительно). В зависимости от общей обстановки, например общее растяжение, в коре поднятия в направлении активно развивающейся впадины может быть ориентирована ось промежуточного главного напряжения $\sigma_{2}$. При общем сжатии в коре впадины в направлении активно растущего поднятия может быть ориентирована также ось промежуточного главного напряжения.

Полученная в in-situ измерениях природная закономерность отвечает теоретическим оценкам возможных изменений горизонтальных напряжений при нагрузке только массовыми силами соответственно в случае чисто упругой и упругопластической реакции среды [Rebetsky, 2008a, 2008b, 2008c].

\section{3. СОВРЕМЕННЫЕ НАПРЯЖЕНИЯ СЕЙСМОАКТИВНЫХ УЧАСТКОВ КОРЫ ПО ТЕКТОНОФИЗИЧЕСКИМ ДАННЫМ}

Алтае-Саяны. По результатам реконструкции природных напряжений для земной коры AC, выполненной на основе данных о механизмах очагов землетрясений в работах [Rebetsky et al., 2007, 2008, $2009,2012]$ совместно с О.А. Кучай (рис. 5), установлено, что земной коре крупных внутригорных впадин, межгорных впадин и котловин наиболее часто отвечает геодинамическая обстановка горизонтального растяжения и сдвига в горизонтальной плоскости (75 \% от площади впадин с данными о напряженном состоянии). Этим обстановкам отвечает субгоризонтальная ориентация оси главного девиаторного растяжения. Режим горизонтального сжатия, которому отвечает субвертикальное положение оси девиаторного растяжения, встречается значительно реже (краевые части Зайсанской впадины, центральный сегмент Тувинской впадины, Тоджинская впадина - 25 \% от площади впадин). Отметим, что в силу особенности сейсмического режима [Zhalkovskii et al., 1995] количество данных о механизмах очагов землетрясений для областей прогибов коры существенно меньше, чем для областей поднятий. Это предопределило здесь большие масштабы усреднения напряжений в процессе реконструкции и интерполяции при районировании коры по видам геодинамического режима.

В то же время в коре поднятий - горные хребты, антиклинали, массивы и др. - преимущественно имеет место режим горизонтального сжатия и сдвига (65 \% от площади поднятий), которому отвечает субгоризонтальное положение оси максимального сжатия. Обстановка горизонтального растяжения встречается в коре поднятий значительно реже (Сангиленское и Таннуольское поднятия, зона перехода от Монгольского Алтая к Горному Алтаю, центральная часть Западного Саяна $35 \%$ от площади поднятий).

Заметим, что Таннуольское поднятие разделяет между собой две крупнейшие межгорные впадины (Восточно-Тувинскую и Убсу-Нурскую). Вероятно, сейсмический режим этих впадин вносит больший вклад в определение механизмов очагов землетрясений этого района. С этих же позиций можно объяснить и распространение режима горизонтального растяжения на Южно-Чуйский хребет вблизи Курайской и Чуйской впадин Горного Алтая.

Еще более важным следствием анализа распределения природных напряжений является установленный факт сопряженного положения участков коры с разным геодинамическим типом напряженного состояния.

Северный Тянь-Шань. Менее четко выражено подобное соотношение морфологии кровли коры и геодинамического режима для СТШ. Здесь результаты тектонофизической реконструкции, выполненной по данным сети КНЕТ совместно с Н.А. Сычевой [Rebetsky, Sycheva, 2008; Rebetsky et al., 2009, 2010, 2012], показывают, что в коре восточной оконечности Чуйской котловины вдоль ее южных границ с Кыргызским хребтом существует область горизонтального растяжения (рис. 6). Суусамырской и Кочкорской внутригорным впадинам отвечают режимы горизонтального сдвига или сдвига с растяжением, для которых ось главного девиаторного растяжения субгоризонтальна. Области горизонтального растяжения также появляются в южном обрамлении Кыргызского хребта вблизи северовосточной границы Суусамырской впадины и вблизи восточного окончания Кочкорской впадины. В коре самих горных хребтов (центральная часть СТШ) геодинамический режим, как правило, - горизонтальное сжатие или сдвиг со сжатием.

Отметим, что для участка Киргизского хребта в западной части исследуемого региона имеются области горизонтального растяжения. Они расположены на северном и южном склонах этого хребта и разделены зоной горизонтального сдвига. Появление этих локальных зон горизонтального растяжения в горном поднятии можно связать с активным в настоящее время участком разлома, выделенным на рис. 6 серым цветом. Согласно работе [Osokina, 1987], в случае правосдвиговогой компоненты смещения по разлому подобные участки растяжения в накрест лежащих секторах и должны формироваться. 

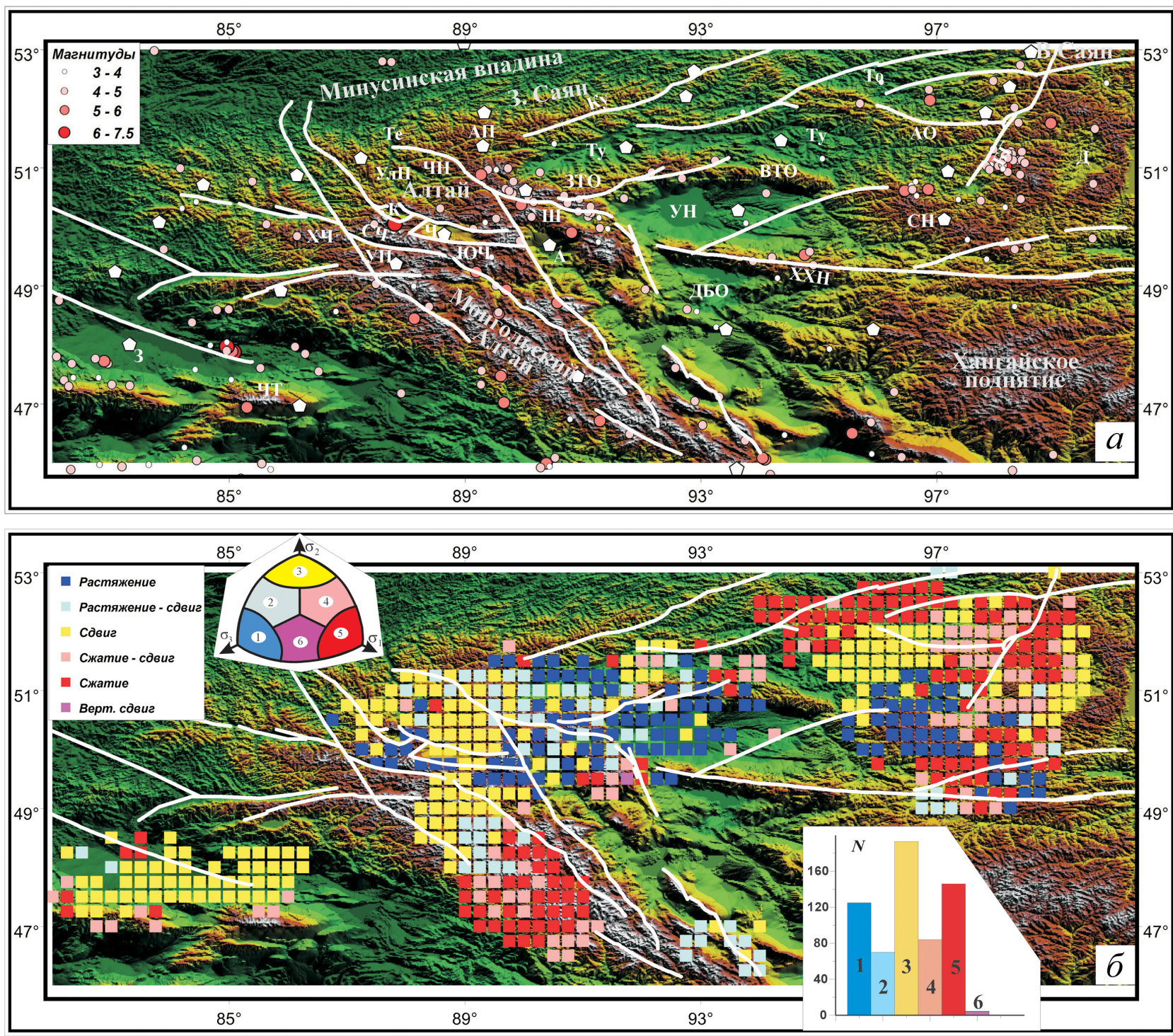

Рис. 5. Топография и эпицентры землетрясений с имеющимися решениями механизмов очагов землетрясений (a), геодинамический тип напряженного состояния (б) в коре АС по результатам тектонофизической реконструкции (из работ [Rebetsky et al., 2012, 2013]).

Главные активные разломы - по В.В. Трифонову [Trifonov et al., 2002]. Пятиугольники - сейсмические станции. Распределение эпицентров землетрясений - из каталога механизмов очагов, используемого для тектонофизической реконструкции напряжений. Геодинамические типы напряженного состояния представлены октантом, построенным на осях главных напряжений (вверху слева), а частота их встречаемости - гистограммой (внизу справа): 1 - горизонтальное растяжение, 3 - горизонтальный сдвиг, 5 - горизонтальное сжатие, 2 - горизонтальное растяжение со сдвигом, 4 - горизонтальное сжатие со сдвигом, 6 - вертикальный сдвиг. Хребты: АО - Академика Обручева, ВТО - Восточный Танну-Ола, ЗТО - Западный Танну-Ола, Ку - Куртушибинский, СЧ - СевероЧуйский, ХХН - Хан Хухий-Нуру, ХЧ - Холзунско-Чуйский, ЧТ - Чингиз-Тарбагатайский, Ш - Шапшальский, ЮЧ - Южно-Чуйский. Плато и нагорья: АП - Алашское, СН - Сенгилен, УП - Укок, УлП - Улаганское, ЧН - Чульшманское. Впадины: А - Ачитнурская, БГ Бусийн-Гол, Д - Дархадская, ДБО - Долина Больших Озер, 3 - Зайсанская, К - Курайская, Те - Телецкая, ТХ - Тере-Холь, То - Тоджинская, Ту - Тувинская, УН -Убсу-Нурская, Ч - Чуйская.

Fig. 5. The topography, earthquake epicentres with focal mechanisms (a); the geodynamic type of the state of stresses (б) in the crust of the Altai-Sayan region, according to the tectonophysical reconstruction [Rebetsky et al., 2012, 2013]).

The major active faults are shown according to [Trifonov et al., 2002]. Seismic stations are shown by pentagons. Earthquake focal mechanism patterns are from the focal mechanism catalogue; the tectonophysical reconstruction of stresses is also based on the data from this catalogue. Geodynamic types of the state of stresses are represented by the octant constructed on the axes of the principal stresses (top left) and their frequency are represented by histogram (bottom right): 1 - horizontal extension, 3 - horizontal shear, 5 - horizontal compression, 2 - horizontal extension with shear, 4 - horizontal compression with shear; 6 - vertical shear. Ridges: AO - Academician Obruchev, BTO - East Tannu-Ola, 3TO - West Tannu-Ola, Ky - Kurtushiba, CY - North Chuya, XXH - Khan Khukhi-Nuru, XY - Kholzun-Chuya, YT Chingiz-Tarbagatai, Ш - Shapshal, ЮЧ - South Chuya. Plateaus and uplands: АП - Alash, СН - Sengilen, УП - Ukok, УлП - Ulagan, ЧН Chulshman. Basins: A - Achitnur, БГ - Busin-Gol, Д - Darkhad, ДБО - Valley of the Big Lakes, 3 - Zaisan, К - Kurai, Tе - Teletsk, ТХ - TereKhol, To - Todzha, Ty - Tuva, УH - Ubsu-Nur, Ч - Chuya. 

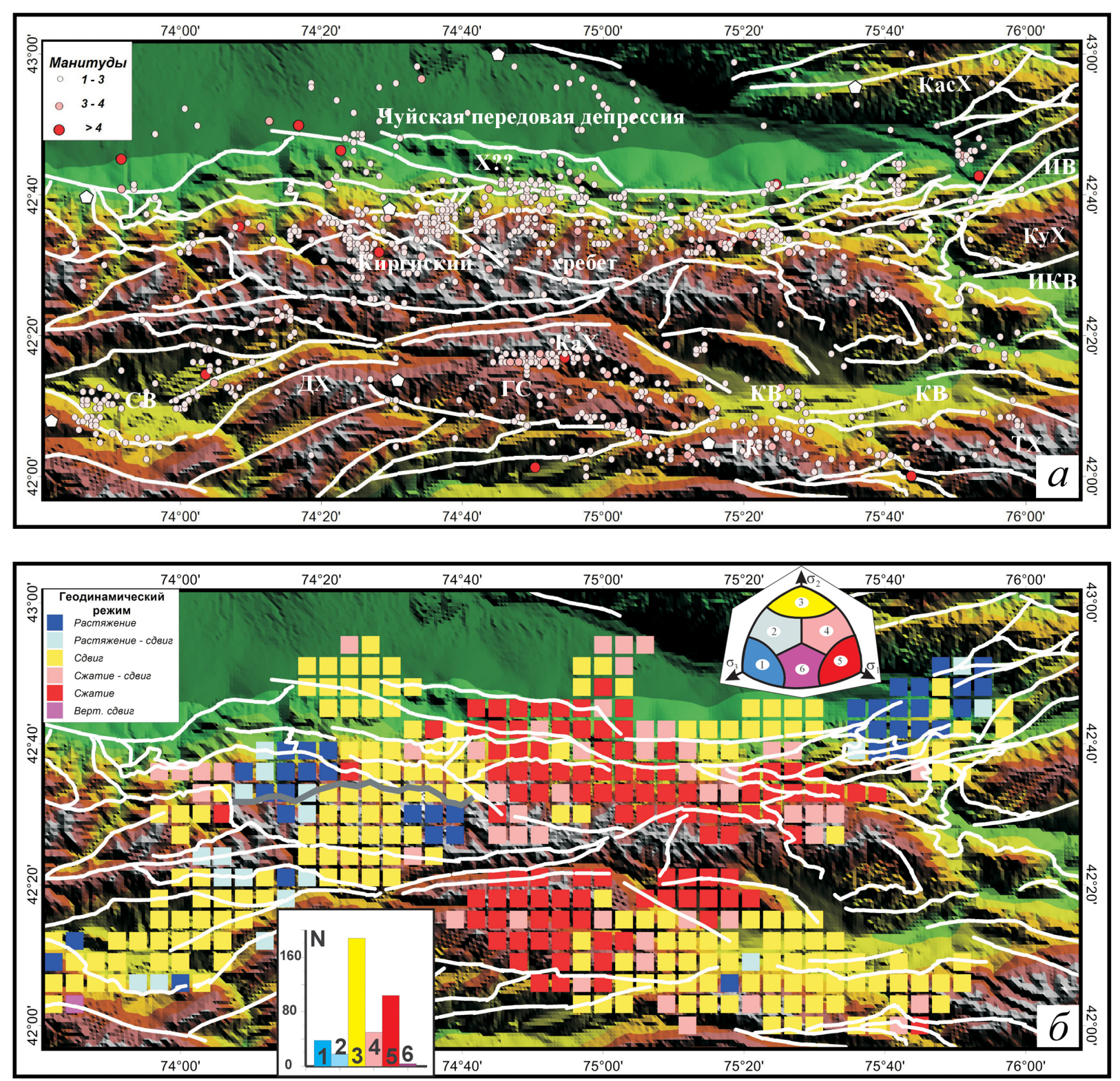

Рис. 6. Топография и эпицентры землетрясений с имеющимися решениями механизмов очагов (a), геодинамический тип напряженного состояния (б) в коре СТШ по результатам тектонофизической реконструкции для глубины 5-15 км (из работы [Ребецкий и др., Геология и геофизика, в печати]).

Разломы по С.И. Кузикову [Ребецкий, Кузиков, Геология и геофизика, в печати]. Пятиугольники - сейсмические станции. Геодинамический тип напряженного состояния см. рис. 5. Хребты: КХ - Киргизский, КуХ - Кунгейский, КаХ - Карамойнок, КасХ - Кастекский, ДХ - Джумгальский, ТХ - Терскей. Впадины: СВ - Суусамырская, КВ - Кочкорская, ИКВ - Иссык-Кульская.

Fig. 6. The topography, earthquake epicentres with focal mechanisms (a); the geodynamic type of the state of stresses (б) in the crust of the Northern Tien Shan region, according to the tectonophysical reconstruction for depths from 5 to $15 \mathrm{~km}$ (from [Rebetsky et al., Russian Geology and Geophysics, in press]).

Faults are shown as defined by S.I. Kuzikov in [Rebetsky, Kuzikov, Russian Geology and Geophysics, in press]. Seismic stations are shown by pentagons. The geodynamic types of the state of stresses are shown in Fig. 5. Ridges: KX - Kirghiz, KyX - Kungeya, KaX - Karamoynok, КасX - Kastek, ДX - Dzhumgal, TX - Terskey. Basins: CB - Suusamyr, KB - Kochkork, ИКВ - Issyk-Kul.

Высокая Азия. Установленные закономерности распределения ориентации главных напряжений в коре AC и СТШ были дополнены еще одной, выявленной по результатам реконструкции напряжений в коре Тибета, Памира и Гималаев - BA [Re- betsky, Alekseev, 2014]. В результате проведенных в этой работе исследований было установлено, что обширным участкам коры центральной части Тибета и Памира, которые представляют из себя высокоподнятые плато (4-5 км), отвечает субгоризон- 
тальная ориентация оси максимального девиаторного растяжения (рис. 7), чему соответствует геодинамический тип напряженного состояния горизонтального растяжения и горизонтального сдвига. В окружении коры указанных плато, там, где наблюдаются высокогорные хребты Памира и Тибета (Куньлунь, Гималаи и др.), имеет место режим горизонтального сжатия, который выявлен и для структур поднятий АС и СТШ.

Наличие горизонтальной ориентации осей максимального девиаторного растяжения в коре поднятий в виде плато Тибета и Памира не соответствует вышеприведенным данным для АС и СТШ, где в коре горных поднятий имеет место субгоризонтальная ориентация осей максимального сжатия. Однако указанный факт не опровергает эти данные, а дополняет. Из него следует, что горные поднятия в виде высокогорных хребтов и поднятия в виде плоских плато могут иметь диаметрально разный тип геодинамического режима.

Отметим, что в коре Сангиленского нагорья, представляющего собой достаточно слабовыраженное по рельефу поднятие, преобладает режим горизонтального растяжения. Таким образом, выявленный для плато Тибета и Памира дополнительный тип напряженного состояния также имеет место и в коре AC.

Как уже говорилось выше при комментировании схемы рис. 4, возможны случаи, когда в смежных участках коры поднятия и впадины практически в одном направлении действуют соответственно $\sigma_{3}$ и $\sigma_{1}$, но возможны сочетания $\sigma_{2}$ и $\sigma_{1}$, а также $\sigma_{3}$ и $\sigma_{2}$. Отмечено, что для таких участков коры наблюдается специфическое мозаичное распределение поддвиговых касательных напряжений, действующих на горизонтальных площадках. Направление этих векторов прежде всего должно подсказывать, какие участки поднятия, окружающего впадину, активно взаимодействуют с нею. Здесь следует вспомнить «правило Карпинского» [Karpin$s k y, 1919]$, определяющего, что рядом с растущим поднятием, на склонах которого интенсивно действуют эрозионные процессы, всегда существуют углубляющиеся впадины, активно аккумулирующие большую часть осадочных пород.

В заключение этой части заметим, что результаты тектонофизической реконструкции опираются на сейсмологические данные о механизмах очагов землетрясений, которые в исследуемых орогенах происходят на глубинах от 3 до 20-25 км при наиболее представительном расположении 1015 км. В связи с этим отмеченные закономерности распределения напряжений в коре поднятий и прогибов также следует относить к глубинам средней коры (10-20 км) и примыкающему к ней некоторому участку верхней (0-10 км).

\section{4. ЛАТЕРАЛЬНЫЕ ДЕФОРМАЦИИ КРОВЛИ КОРЫ ПО ГЕОФИЗИЧЕСКИМ ДАННЫМ}

При анализе данных GPS-геодезии часто возникают дискуссии о применении той или иной системы координат и выборе точек закрепления при расчете векторов перемещений. Так, в случае расчета векторов перемещений Центральной Азии в системе координат ITRS для пунктов наблюдений ITRF2000 поле векторов перемещений определяет движение большинства пунктов GPS-наблюдений в одном - восток-юго-восточном - направлении (скорости перемещений 25-27 мм/год) [San'kov et al., 2011]. В системе ITRS при внесении поправок согласно данным пунктов ITRF2000 нулевые смещения отвечают геоцентру Земли. В случае закрепления (присвоения нулевых латеральных перемещений) одного из GPS-пунктов вся картина распределения векторов скоростей перемещений резко изменяется. Изменение в пределах региона реперного пункта способно серьезно изменить ориентацию векторов перемещений.

0 проблемах расчета латеральных деформаций по данным GPS. Таким образом, представление GPS-измерений в виде векторов горизонтальной скорости не инвариантно к системе отсчета. Пересчет перемещений в приращения горизонтальных деформаций, отвечающие периоду наблюдений, позволяет снять проблему реперных (закрепленных) точек и уменьшить зависимость наглядности визуализации результатов расчета от выбора системы координат. В частности, используя данные GPS-геодезии, можно методом триангуляционных расчетов получить данные о латеральных деформациях земной поверхности. При подобных расчетах определяются три компоненты деформаций, действующие на поверхности коры в латеральном направлении (две продольные деформации и деформация сдвига в горизонтальной плоскости, например $\varepsilon_{i j}$ при $i, j=x, y$, где $x$ - направление на север, а $y$ - направление на восток), а затем определяются направления осей и величины главных продольных латеральных деформаций.

В работе [San'kov et al., 2011] представлены результаты расчета главных приращений деформаций (рис. 8) для Саян, Хангая, Гоби и западных областей Байкала. Здесь узлы триангуляционной сети располагались друг от друга в среднем на расстояниях 200-500 км. Эти расстояния определяют масштаб усреднения деформаций, рассчитываемых из GPS-наблюдений. Полученные на таких базах скорости деформаций укорочения не превышают значений 4·10-8 1/год. Поскольку области высокой интенсивности субмеридионального и северо-восточного укорочения соседствуют с областями меньшей интенсивности укорочения и даже 

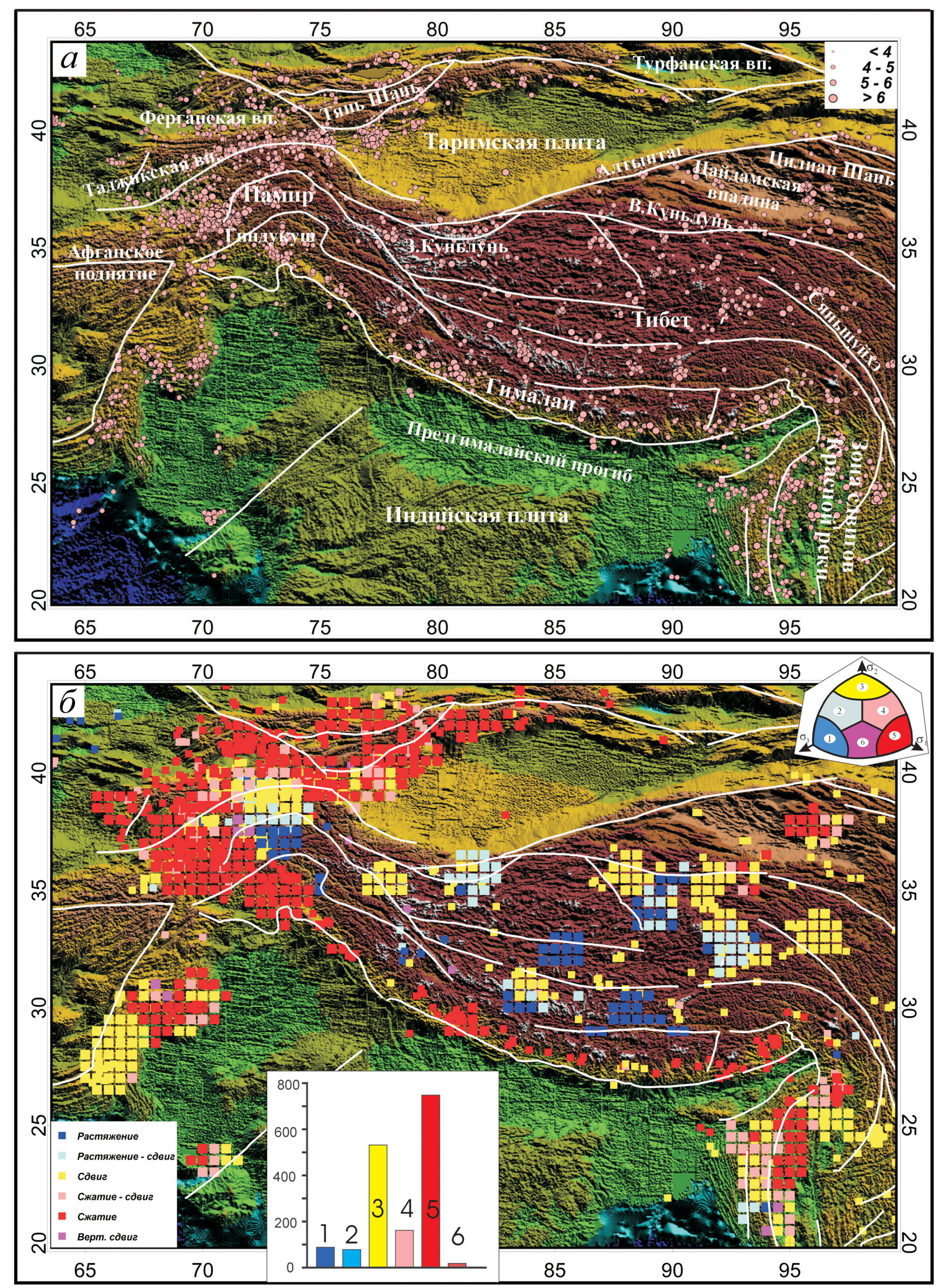

Рис. 7. Параметры геодинамического режима в коре ВА по результатам тектонофизической реконструкции природного напряженного состояния (из работы [Rebetsky, Alekseev, 2014]): a - разломы по работе [Burtman, 2012] и эпицентры анализируемых землетрясений; б - геодинамический тип напряженного состояния.

Fig. 7. Parameters of the geodynamic regime in the crust of the High Asia, according to the tectonophysical reconstruction of the natural state of stresses (from [Rebetsky, Alekseev, 2014]): $a$ - faults shown according to [Burtman, 2012] and epicentres of the analyzed earthquakes; $\sigma$ - the geodynamic type of the state of stresses. 


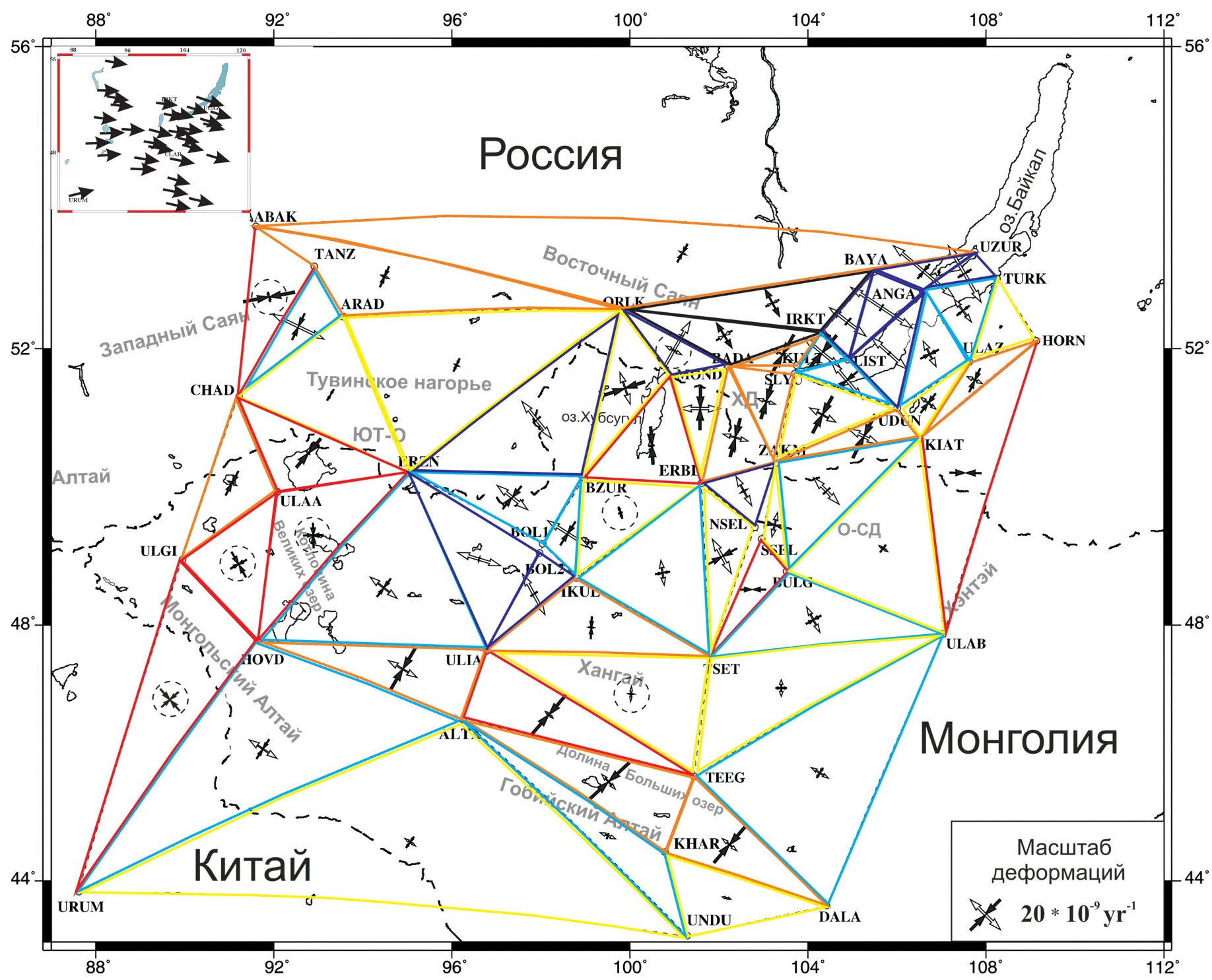

Рис. 8. Деформации земной поверхности Монголо-Сибирского региона по результатам триангуляционных расчетов данных GPS-геодезии (рисунок из работы [San'kov et al., 2011] с дополнениями).

Рисунок доработан путем выделения цветом областей разной интенсивности и знака латеральных деформаций. Участки латерального расширения (синие тона), сжатия (красно-коричневые тона) и малого изменения латеральной площади (желтый цвет). В верхнем левом углу показано поле векторов приращений перемещений в системе ITRF2000.

Fig. 8. Deformation of the ground surface in the Mongolian-Siberian region, according to results of triangulation calculations using GPS geodesy data (the figure from [San'kov et al., 2011] with additions).

The figure is modified by highlighting the areas that differ in the intensity and signs of lateral deformation. Colour codes: blue - lateral extension sites; red-brown - lateral compression sites; yellow - sites with small changes in the lateral square area. Top left corner - the field of increment displacement vectors in ITRF2000.

в некоторых случаях удлинения, усреднение скоростей деформаций на базах в первые тысячи километров приводит к снижению значений скорости максимального укорочения до 10-9 1/год [Timofeev, 2012].

Если расчеты по данным GPS-геодезии сопроводить гипотезами о том, что все определяемые приращения деформации являются необратимыми (чисто пластическая реакция геосреды) и что в процессе течения не происходит изменения объема (отсутствие дилатансии или компакции)

$$
\theta=\varepsilon_{x x}+\varepsilon_{y y}+\varepsilon_{z z}=0
$$

то можно рассчитать и приращение продольной деформации в третьем - вертикальном - направлении $\left(\varepsilon_{z z}\right)$. Используя другой крайний вариант реакции горных пород на деформирование, можно 
считать, что все приращения деформации упругие. Полагая коэффициент Пуассона 0.25 (наиболее встречаемое его значение для горных пород), из равенства нулю вертикального нормального напряжения можно оценить приращение деформации в вертикальном направлении:

$$
\varepsilon_{z z}=\frac{v}{1-v}\left(\varepsilon_{x x}+\varepsilon_{y y}\right) .
$$

Оба этих варианта расчета позволяют получить данные о компонентах трехмерного тензора приращений общих тектонических деформаций.

Заметим, что гипотеза о том, что все деформации, рассчитываемые по данным GPS-геодезии, являются необратимыми, фактически предполагает установившуюся стадию упругопластического деформирования без упрочнения либо стадию ползучего течения в условиях постоянной скорости нагружения. На этой стадии не происходит изменения напряженного состояния (нет приращений упругих деформаций), а только идет накопление необратимых деформаций. Отметим также, что высказанная выше гипотеза о неизменности объема при деформировании отвечает отсутствию дилатансии и в приложении к породам верхней коры является достаточно грубым приближением, так как именно в коре наиболее развиты дилатансионные процессы [Nikolaevsky, 1996].

Используя предположения (1) или (2), можно установить, какая из главных деформаций имеет место в вертикальном направлении. В наших расчетах индексы главных приращений деформаций были расставлены по правилу $\varepsilon_{1} \geq \varepsilon_{2} \geq \varepsilon_{3}$ при положительных значениях для деформации удлинения. Использование главных деформаций наиболее удобно для интерпретации получаемых результатов, поскольку позволяет при определенных гипотезах говорить и об ориентации главных осей напряжений.

Отметим одно важное обстоятельство. В классической механике положительным значениям деформаций - удлинениям - отвечают напряжения растяжения, которые также положительны, а отрицательным деформациям - укорочениям - сжимающие напряжения, имеющие отрицательные значения. Соответствие знаков напряжений и деформаций определяется законом Гука, который связывает тензор напряжений и деформаций. В зарубежной тектонофизике, а также в работах некоторых научных школ России используется правило знаков для напряжений, принятое не в классической механике, а в горном деле. Там за положительные значения напряжений принимаются напряжения сжатия. Подобное правило выглядит вполне разумным, так как практически повсеместно значения полных напряжений, учитывающих литостатическое давление, - сжимающие. Однако оно приводит к противоречию, как только возникает необходимость связывать напряжения и деформации. В этом случае оказывается, что надо за положительные деформации принимать деформации укорочения, что противоречит физическому смыслу этих терминов (укорочение - уменьшение длины).

Латеральные деформации Центральной Азии. Применяя представленный выше подход по оценке компонент трехмерного тензора общих тектонических деформаций к данным, полученным для AC в работе [San'kov et al., 2011], отмечаем, что в большом числе случаев оси главных приращений деформаций показывают направления максимального укорочения (черные стрелки) и удлинения (белые стрелки) в горизонтальной плоскости. Также существуют участки коры, для которых в латеральном направлении обе оси главных деформации определяют либо сокращение, либо растяжение. Такие определения осей главных деформаций мы поместили в кружок (7 определений). На рис. 8 красно-коричневым (24 тр.) и синим (26 тр.) цветом маркированы треугольники сети, для которых средняя деформация в латеральном направлении отвечала уменьшению и увеличению площади соответственно. Красный цвет (9 тр.) отвечал ситуации, когда в обоих главных направлениях имело место укорочение или когда укорочение в одном направлении на порядок и более превышало удлинение в другом. Темно-синий тон (13 тр.) отвечал обратной ситуации для латерального расширения. Желтым цветом (9 тр.) маркированы треугольники, для которых наблюдались существенно малые латеральные приращения деформации. Заметим, что треугольникам синих тонов отвечает вертикальное укорочение, а треугольникам красно-коричневого цвета - вертикальное удлинение.

Следует заметить, что даже если исключить треугольники с расширением площади, расположенные непосредственно в пределах о. Байкал (8 тр.), то их общее число составляет 17 , и занимаемая площадь вполне сопоставима с треугольниками сокращения площади (25 тр.). Заметим также, что существует близкое и контрастное соседство треугольников латерального расширения и сокращения площадей.

Из представленных на рис. 8 данных замечаем, что крупным котловинам и депрессиям (южная часть Долины Больших Озер, Бусийнгольская впадина, озеро Байкал), как правило, отвечают средние латеральные деформации расширения (треугольники темно-синего и голубого цвета), а крупным горным поднятиям (северная часть Монгольского Алтая, Восточный Саян, Хамар Дабан) - сред- 
ние латеральные деформации сокращения (треугольники красного и светло-коричневого цвета). Из этого правила выпадают участки коры озера Хубсугул, северные части Долины Больших Озер, южная часть Монгольского Алтая. Но здесь следует заметить, что для озера Хубсугул два южных узла расчетного треугольника находились в областях поднятий Северо-Монгольского массива, западные узлы треугольника Долины Больших озер находились на Гобийском Алтае, а юго-западный узел треугольника для Монгольского Алтая выходил далеко за его пределы.

Следует отметить также, что для большого числа участков коры наблюдаются низкие уровни деформаций: Тувинское нагорье, Хангай, Орхон-Селенгинская депрессия, Гобийский Алтай. При этом в расчетные треугольники Тувинского нагорья входили как области поднятий, так и Тувинская котловина, а южный узел треугольника для Гобийского Алтая выходил достаточно далеко за его пределы.

Деформации Тянь-Шаня. В работах [Zubovich et al., 2004, 2007; Kostyuk, 2009; Kostyuk et al., 2010; Kuzikov et al., 2009] были представлены результаты геодезических наблюдений GPS по данным региональной сети станций Южного Казахстана и ТяньШаня, дополненные группой GPS-пунктов сети HC PAH в г. Бишкек. Здесь GPS-станции располагались на меньших расстояниях, так как плотность сети для СТШ составляла около 20 км. Для территории Тянь-Шаня, являющейся более активной в тектоническом отношении и имеющей более плотную сеть станций, скорости деформаций субмеридионального укорочения более высокие, чем для AC, и достигают значений 5·10-7 1 /год. Для южных областей Казахского щита Евразийской плиты скорости деформаций укорочения резко падают до 10-9 1/год.

На рис. 9 представлены результаты расчетов средних латеральных приращений деформаций, отражающих изменения площадей (латеральная дилатация) для СТШ [Kostyuk, 2009]. Большая часть исследуемого региона испытывает среднюю латеральную деформацию сжатия. Результаты расчетов поля деформаций для СТШ также показывают, что здесь существуют участки, где латеральная дилатация имеет не только значения, пониженные относительно средних (светло-голубые тона), но где ее знак изменяется на противоположный - среднее латеральное растяжение (желтые и светло-коричневые тона). Эти области хорошо коррелируют с участками геодинамического режима горизонтального растяжения и оконтуривающего его режима горизонтального сдвига, выделенными для коры СТШ в результате тектонофизического анализа механизмов очагов землетрясений (см. рис. 6).
Средние скорости субширотного удлинения и субмеридионального укорочения восточной части Центрального Тянь-Шаня (ЦТШ) около 10-8 1/год, а в западной - 10-9 1/год [Laverov, 2005]. Отмечается, что участки наибольшего субмеридионального (вблизи $78^{\circ}$ в.д.) сокращения - 5·10-8 1/год - приходятся на наиболее высокогорный рельеф (пики Хан-Тенгри, Победы), а наименьшее субмеридиональное сокращение составляет $2 \cdot 10^{-8} 1$ /год в районе $72-73^{\circ}$ в.д., и эти рассчитываемые длины линий проходят через Ферганскую долину.

Расчеты средней скорости изменения латеральных деформаций, выполненные в работе [Zubovich et al., 2001], показали, что наибольшее латеральное сокращение происходит в районах Иссыккульской, Кегенской, Чуйской и Суусамырской впадин, т.е. площади впадин сокращаются быстрее, чем площади хребтов. Это не обнаружено для Илийской и Таласской впадин. В работе [Tychkov et al., 2008], где выполнены расчеты деформаций для участка ЦТШ в окрестности о. Иссыккуль, получен несколько отличный результат. Здесь площадь Иссыккульской впадины испытывает общее латеральное сокращение, но к северу от нее (Заилийский Алатау и юго-западные участки Илийской впадины), а также вдоль ее юго-западной границы наблюдаются области латерального расширения. Подобные различия в результатах, базирующихся на одних и тех же данных, связаны с методами их обработки. В работе [Zubovich et al., 2001] усреднение результатов происходит на стадии расчета деформаций, а в работе [Tychkov et al., 2008] - после расчета деформаций.

Данные наземных измерений (светодальномерные наблюдения) показывают, что ширина Таджикской депрессии увеличивается, несмотря на то, что она, согласно концепции тектоники литосферных плит, находится в обстановке горизонтального сжатия [Guseva et al., 1993]. Это подтверждается сейсмологическими данными, определяющими субгоризонтальную ориентацию осей удлинения тензора сейсмотектонических деформаций для крупных приосевых участков депрессии [Lukk et al., 2008]. Также субмеридиональное и общее латеральное расширение со скоростью порядка $10^{-6}-10^{-7} 1 /$ год наблюдалось на кварцевых деформографах для станций Алматинского прогностического полигона, расположенных в предгорьях хребта Заилийского Алатау [Tikhomirov et al., 2001]. Повторное нивелирование показывает, что Чуйская, Иссыккульская и Ферганская впадины обладают устойчивым погружением [Abdrakhmatov, Tsurkov, 1991].

Обобщение GPS-данных. Можно утверждать, что данные наземных наблюдений за деформациями поверхности не опровергают полученный после 


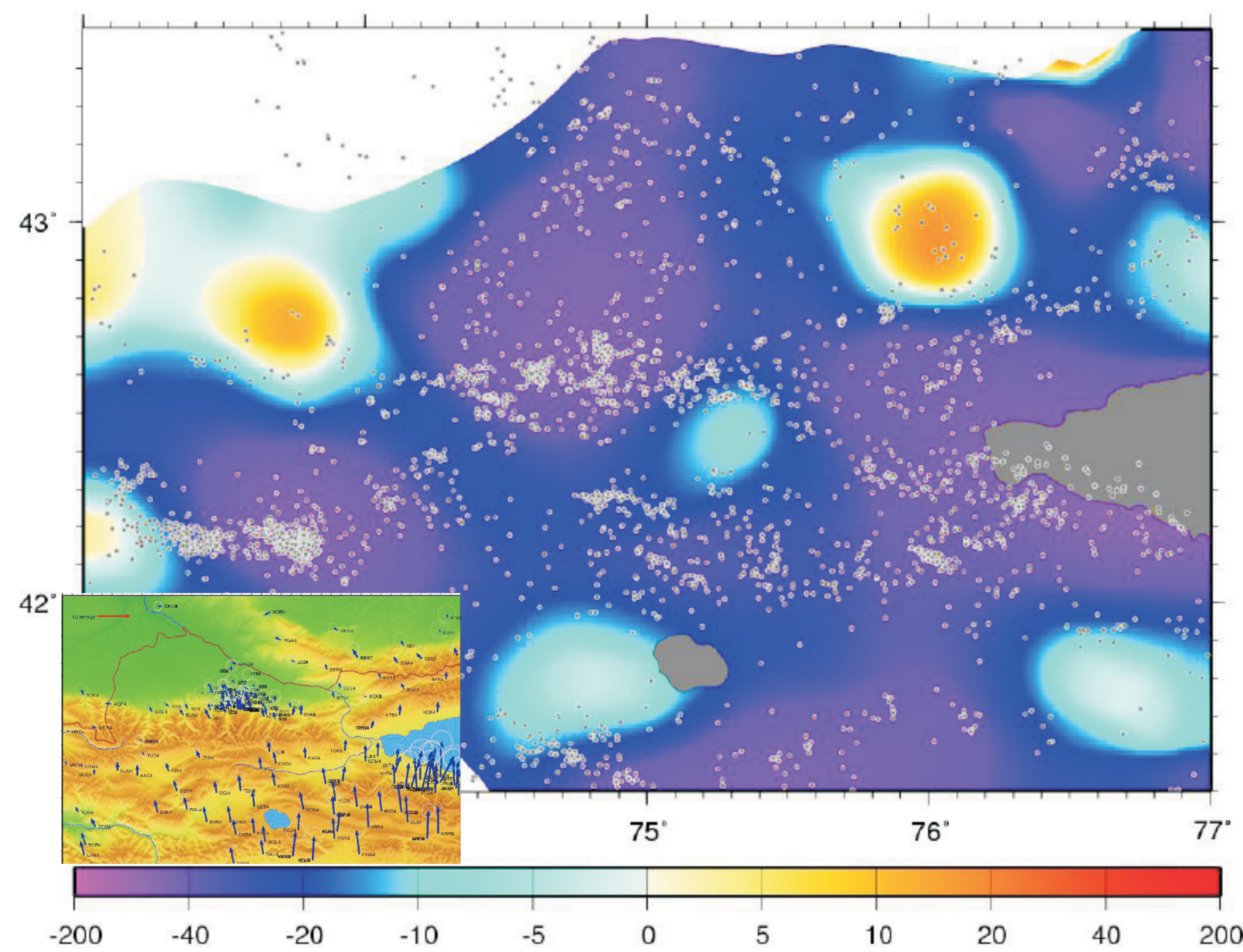

Рис. 9. Поле скоростей латерального изменения площадей (дилатация) по данным GPS-геодезии и эпицентры землетрясений (точки серого цвета) по данным локальной сети KNET для СТШ (рисунок из работы [Kostyuk, 2009]). Шкала деформаций 10-9 1/год. В нижнем левом углу показано поле векторов приращений перемещений.

Fig. 9. The field of velocities of lateral changes of the square area (dilation), according to GPS geodesy data, and earthquake epicentres (grey dots), according to the data from the KNET local network for the Northern Tien Shan region (the figure from [Kostyuk, 2009]). Strain scale 10-9 1/ year. Bottom left corner - the field of incremental displacement vectors.

анализа реконструкции тектонических напряжений (см. рис. 5,6$)$ результат, определяющий более частое представительство режима горизонтального сжатия в областях поднятий и режима горизонтального растяжения в областях прогибов. Очевидно, что чистота выделения подобных ситуаций по данным GPS-геодезии сильно зависит от размеров триангуляционной сети и попадания расчетных треугольников сети в структуры одного геодинамического режима.

Следует отметить, что выявленные по данным GPS-геодезии интенсивные латеральные деформации для межгорных впадин, которые наблюдаются как для АС, так и для ЦТШ, противоречат часто используемому положению о большей жесткости ко- ры впадин, чем коры горных поднятий [Abdrakhmatov et al., 2001; Buslov et al., 2003; Tychkov et al., 2008]. Введение этой гипотезы связывают с меньшей сейсмической активностью коры впадин, а также существующими здесь повышенными скоростями сейсмических волн [Knauf, 1976; Yudakhin, 1978]. Таким образом, пониженный уровень сейсмической активности связан не с уровнем интенсивности их деформирования, а определяется какими-то другими причинами.

Согласно концепции тектоники литосферных плит, напряжения, возникающие на границах их контакта, создают обстановку горизонтального сжатия в областях горно-складчатых орогенов и приводят к формированию поднятий и утолщению 
коры [Dewey, Bird, 1970; Molnar, Tapponnier, 1975]. Однако, если утолщение коры этих регионов было бы связано с латеральным сжатием (меридиональным сжатием для АC), то отсюда обязательно должно было следовать латеральное сокращение площади этих регионов, причем это сокращение должно было наблюдаться в областях как поднятия, так и прогиба коры. Но результаты расчета деформации из данных GPS-геодезии, выполненные на больших площадях, не показывают преимущественного латерального сжатия участков коры горно-складчатых орогенов. Как следует из данных для АС (см. рис. 5), площади областей латерального расширения и латерального сокращения приблизительно одинаковые. Для этого региона наблюдается определенная взаимная компенсация областей латерального сокращения и расширения площадей поверхности коры.

\section{5. ДАННЫЕ ПОЛЕВЫХ ТЕКТОНОФИЗИЧЕСКИХ ИССЛЕДОВАНИЙ}

В этом разделе будет выполнен обзор тектонофизических работ, связанных с изучением палеонапряжений в зонах сопряжения впадин и поднятий, а также для крупных складок. Исследования выполнялись на основе анализа геологических данных о сдвиговых разрывах и трещинах. Поскольку крупные складки, как правило, формируют современный рельеф кровли коры, данные о напряженном состоянии в момент формирования складок также позволяют сделать вывод о закономерности механизма горообразования.

В качестве примера результатов тектонофизических исследований палеонапряжений области горно-складчатых орогенов приведем широко известную работу М.В. Гзовского для Байджансайского антиклинория горного хребта Каратау (см. pис. 1) [Gzovsky, 1959, 1963]. Эта классическая тектонофизическая работа, выполненная в пятидесятых годах прошлого века, в России до сих пор не имеет аналогов по комплексности и фундаментальности. В ходе проведенных исследований происходила апробация многих полевых, экспериментальных (физическое моделирование) и теоретических методов изучения складок и разрывов, которые в дальнейшем и создали основу тектонофизики [Gzovsky, 1975].

Важно отметить, что исследование напряжений проводилось с использованием метода сопряженных пар сколов (метод М.В. Гзовского) и геологических методов анализа мелких структурных форм (кливаж, будинаж, трещинки отрыва, ...). Это давало возможность говорить о восстановлении поля напряжений, охватывавшего крылья, свод, пери- клинали и ядро антиклинальных частей складок, в период их формирования в позднем палеозое.

В результате исследований М.В. Гзовского было установлено, что в Байджансайском антиклинории наиболее крупным складчатым структурам - антиклиналям (поперечный размер - первые километры) - отвечает субвертикальная ориентация осей максимального сжатия $\sigma_{3}$ и субгоризонтальная для осей минимального сжатия $\sigma_{1}$ (рис. $10, a$ ). Траектории осей $\sigma_{1}$ стремятся быть параллельными наклону крыльев антиклинали. Данная закономерность фиксировалась по характерным сопряженным парам сколовых трещин взбросового типа, наблюдаемым в крыльях антиклиналей, и грабенов в его сводовой части.

Для синклиналей данные о разрывных нарушениях в основном относились к их крыльям, т.е. зонам их сопряжения с антиклиналями складок. Оси максимального сжатия здесь имели относительно пологий наклон в сторону ядра антиклинали, что позволило М.В. Гзовскому предположить их субгоризонтальную ориентацию в срединной части синклинали. На рис. 10, б, траектории этих осей имеют пологий выгиб вверх, а оси максимального девиаторного растяжения веерообразно расходятся от ядра синклинали. Промежуточная ось главного напряжения $\sigma_{2}$ ориентирована вдоль шарниров складок в ее антиклинальной и синклинальной частях.

Таким образом, в Байджансайском антиклинории наиболее крупные складки (первый ранг) отвечали режиму поперечного изгиба. М.В. Гзовский показал, что складчатые структуры разного ранга крупные (первого и второго порядка) и дополнительные (третьего, четвертого и т.д.) - доставляют информацию о разных масштабах напряжений, действующих в горных массивах. Так, для дополнительных складок полученные данные их напряженного состояния в момент формирования говорили о действиях механизмов как продольного сжатия, так и поперечного изгиба.

Отметим, что ориентация осей главных напряжений, отвечающая также поперечному изгибу, была установлена и в работе [Marinin, 2013] для Семисамской антиклинали (Северо-Западный Кавказ). При этом для реконструкции палеонапряжений использовались данные о совокупностях зеркал скольжения и метод катакластического анализа разрывных смещений [Rebetsky, 1999, 2007].

Приведя выше результаты исследований М.В. Гзовского в формулировках, близких к авторским, дадим теперь им небольшой комментарий. М.В. Гзовский объяснял полученную закономерность распределения осей главных напряжений для антиклинали и синклинали (рис. 10) действием механизма поперечного изгиба, особенности которого исследовались на моделях из пластичных 


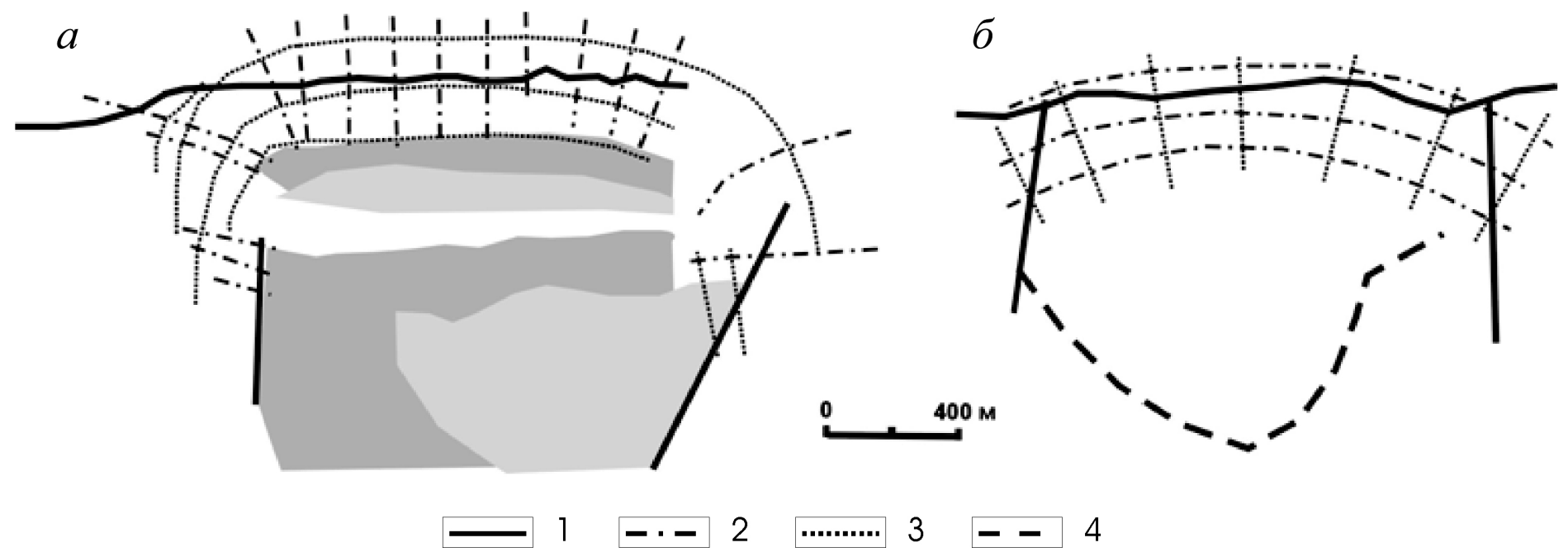

Рис. 10. Характер траекторий главных осей палеонапряжений, полученных М.В. Гзовским для Манчабырской антиклинали $(a)$ и Аксуранской синклинали (б) Байджансайского антиклинория.

1 - разломы; 2 - траектории осей алгебраически минимального главного напряжения $\sigma_{3} ; 3$ - траектории осей алгебраически максимального главного напряжения $\sigma_{1} ; 4$ - контур Аксуранской синклинали. Рисунок в упрощенной форме взят из работы [Gzovsky, 1963].

Fig. 10. Trajectories of the principal axes of palaeostresses estimated by M.V. Gzovsky for the Manchabyr anticline (a) and the Aksuran syncline (б) of the Baydzhansai anticlinorium.

1 - faults; 2 - trajectories of axes of the algebraically minimum principal stress $\sigma_{3} ; 3$ - trajectories of axes of the algebraically maximum principal stress напряжения $\sigma_{1} ; 4$ - contour of the Aksuran syncline. The figure in the simplified form is taken from [Gzovsky, 1963].

глин. В моделях под антиклиналями и синклиналями задавалось вертикальное движение штампа, которое формировало поднятие и опускание с соответствующей структурой разрывов и траекторий главных деформаций. Как показали результаты моделирования, выполненного сотрудниками лаборатории М.В. Гзовского (Е.И. Черткова, Ма Цзинь), на крыльях как антиклиналей, так и синклиналей формируются взбросы, что позволяет соединить эти две тектонофизические модели [Gzovsky, 1963, puc. 130, c.386]. В сводовой части моделируемой антиклинали наблюдаются грабенообразные структуры, что соответствует данным о природных напряжениях, полученных в этих частях структуры. Но вот в срединной части прогибов (синклиналей) в моделях слои сохраняли спокойное залегание, эквивалентное начальной стадии, до опускания штампа. Это подсказывает, что в указанной части модели имеет место чисто гравитационное напряженное состояние с субвертикальной ориентацией осей максимального сжатия. Данный результат позволил поставить под сомнение субгоризонтальное положение траекторий максимального сжатия в срединной части синклинали, показанное в работе [Gzovsky, 1963].

В дополнение к данным, полученным М.В. Гзовским, можно также привести результаты палеостресс-анализа В.С. Милеева [Mileev, Rozanov, 1976] для складок Улутау Северного Казахстана (см. рис. 1). В этих исследованиях также использовался метод сопряженных пар сколов М.В. Гзовского, дополнявшийся анализом мелких структурных форм и линейности. В результате было установлено, что как для антиклиналей, так и для синклиналей имеет место одинаковый геодинамический тип напряженного состояния. Во всех случаях поперек шарниров и параллельно зеркалу складок действует максимальное сжатие. Для некоторых антиклиналей исследуемого района вдоль шарниров складок действовало минимальное сжатие (алгебраически максимальное главное напряжение), а в других случаях в этом направлении было ориентировано промежуточное главное напряжение. Таким образом, складки Улутау являются складками продольного изгиба. Отметим, что в исследованиях М.В. Гзовского, выполненных для Байджансайского антиклинория, для складок меньшего ранга также была отмечена ориентация осей максимального сжатия, параллельная слоистости, при возможной смене ориентации двух других главных осей напряжений.

В работах А.В. Парфеевец и В.А. Санькова изучалось палеонапряженное состояние Восточного Саяна и юго-западной части Байкальской рифтовой системы [Parfeevets, San'kov, 2006]. Отличием данной работы от представленных выше исследований М.В. Гзовского и В.С. Милеева было использо- 


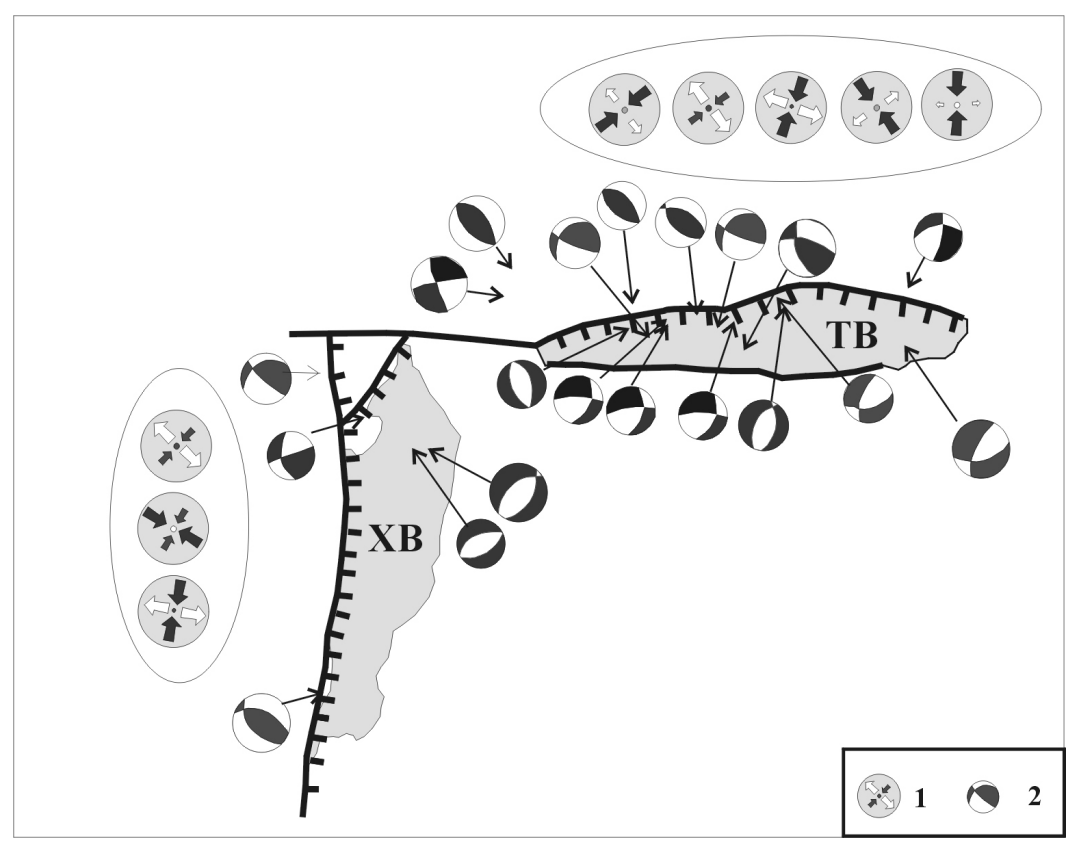

Рис. 11. Характер напряженного состояния Хубсугульской (ХВ) и Тункинской (ТВ) впадин.

Показаны наиболее представительные данные о палеостресс-состояниях (1), полученные в зоне сочленения впадин с окружающими горными поднятиями [Parfeevets, San'kov, 2006]. Толстыми линиями показаны основные разломы, берг-штрихи показывают направление падения сместителя. Механизмы очагов землетрясений (2) показаны только для коры впадины и ближайшего окружения по работе [Melnikova et al., 2001]; стрелки показывают положение эпицентра, области белой заливки у отдельных механизмов очагов определяют положение оси $P$, области темной - оси $T$.

Fig. 11. The state of stresses of the Khubsugul (XB) and Tunkinskaya (TB) basins.

The figure shows the most representative data of the state of paleostresses (1), published in [Parfeevets, San'kov, 2006], for the junction area of the basins and the surrounding mountain ridges. Thick lines show the main faults, slope lines indicate the fault plane dip. Earthquake focal mechanisms (2) are shown only for the crust of the basin and its neighboring structures, according to [Melnikova et al., 2001]; arrows show positions of epicentres; for individual focal mechanisms, white- and dark-coloured segments refer to positions of $P$ and $T$ axes, respectively.

вание метода right-dihedra Ж. Анжелье [Angelier, Mechler, 1977], базирующегося на анализе совокупностей зеркал скольжения. Этот метод близок к методу катакластического анализа разрывных смещений Ю.Л. Ребецкого.

В нашей работе мы остановимся на результатах исследований [Parfeevets, San'kov, 2006] для Хубсугульской и Тункинской рифтовых впадин. Важно отметить, что впадины расположены в непосредственной близости друг от друга (рис. 11) и первая из них имеет субмеридиональное, а вторая - субширотное простирание. Этим впадинам свойственны краевые разрывы кинематического типа в виде сбросов.

После группирования разных типов стресс-состояний было сделано предположение о существовании трех временных этапов деформирования исследуемых районов: ранний этап субширотного растяжения, эпизод запад-северо-западного сжатия и поздний сдвиговый этап с северо-восточной ориентацией оси максимального сжатия. Следует отметить, что анализ исходных стресс-состояний в точках наблюдения, приведенных в работе [Parfeevets, San'kov, 2006], показывает, что достаточно часто имелись случаи, когда в очень близких по расположению точках в одном и том же направлении были ориентированы оси главного напряжения максимального сжатия и максимального девиаторного растяжения. Эти состояния далее разносились в разные временные этапы деформирования.

В работе [Parfeevets, San'kov, 2006] кроме исследования палеонапряженного состояния областей Хубсугульской и Тункинской впадин также изучалось напряженное состояние Тувинского нагорья. Эта область попадает в район изучения современного напряженного состояния, результаты которого представлены на рис. 5, 6, поэтому интересно сравнить результаты обеих реконструкций. Сразу заметим, что большинство определений палеостресс-состояний относились к участкам горных поднятий. Как следует из рис. 4.16 работы [Parfeevets, San'kov, 2006], основные геодинамические типы напряженных состояний Джебашского и во- 
сточной части Таннуольского поднятия представляют собой горизонтальное сжатие и горизонтальный сдвиг. Существовало два определения стресссостояния в западной части Тувинской впадины, которые также показали горизонтальное сжатие и сдвиг со сжатием. Однако оба они также приходились на растущее в пределах этой впадины поднятие. Таким образом, эти исследования также подтверждают выявленный нами факт режима горизонтального сжатия или сдвига в областях растущих поднятий.

\section{6. ОБСУЖДЕНИЕ}

О динамопаре напряженного состоянии коры поднятия и впадины. По результатам тектонофизической реконструкции природных напряжений, опирающейся на сейсмологические данные о механизмах очагов землетрясений, установлено: 1) кора внутриконтинентальных горно-складчатых орогенов СТШ и АС в масштабе осреднения, сопоставимом с мощностью коры, имеет существенно неоднородное напряженно-деформированное состояние; 2) в коре крупных участков поднятий в виде высокогорных хребтов в большинстве случаев (около 65 \% от их площади) напряженное состояние отвечает ориентации оси максимального сжатия в субгоризонтальном направлении (геодинамические режимы горизонтального сжатия и сдвига), а в коре крупных участков прогибов в большинстве случаев (около 75 \% от их площади) напряженное состояние отвечает ориентации оси максимального растяжения (девиаторного) в субгоризонтальном направлении (геодинамические режимы горизонтального растяжения и сдвига); 3 ) в коре крупных по площади и высоких горных плато (Памир, Тибет, Тувинское нагорье) ориентация осей девиаторного растяжения субгоризонтальная; 4) величины изотропного давления, усредненные по площади коры горно-складчатых орогенов СТШ, AC и ВА, близки к литостатическому давлению, что дает уровень дополнительных (по отношению к чисто гравитационному напряженному состоянию) напряжений горизонтального сжатия около 1.3 кбар; 5) разброс в результатах расчета тектонического давления составляет около 0.2-0.4 от литостатического давления, что приводит к появлению областей высокого уровня девиаторных напряжений как в зонах повышенного тектонического давления, так и там, где оно понижается.

Результаты палеостресс-анализа для двух рифтовых впадин Восточного Саяна - Хубсугульской и Тункинской - показали, что в их краевых частях в близких точках наблюдения часто имеют место два антиподных стресс-состояния, для которых в близ- ких направлениях ориентированы оси главных напряжений максимального и минимального (девиаторного растяжения) сжатия. Авторы этих исследований [Parfeevets, San'kov, 2006] разнесли эти стресс-состояния в разные временные этапы деформирования региона.

Однако следует заметить, что по вполне понятным причинам (обнаженность и доступность) большинство точек сбора данных о зеркалах скольжения находилось на границе впадин и окружающих их горных поднятий. Эти участки следует рассматривать как переходные зоны, в которых могут формироваться структуры разного генезиса из-за латерального смещения границы впадина-поднятие. Подобные смещения могут носить как направленный, так и колебательный характер [Belousov, 1976]. В силу этого следует согласиться с В.В.Ружичем, признав, что эти результаты отражают разный тип напряженного состояния формирующейся в коре рифтовой впадины и ее горного окружения.

Ранее в работах В.В. Ружича было установлено наличие надвигов в северном обрамлении Тункинской впадины [Ruzhich et al., 1972], в Прихубсугулье [Ruzhich, Khil'ko, 1985] и в районе Чарской впадины [Ruzhich, 1978]. На основе этих данных В.В. Ружичем было высказано предположение об одновременном сосуществовании обстановки горизонтального растяжения во впадинах и горизонтального сжатия в горном окружении.

Эта гипотеза, с одной стороны, отвечает нашим результатам для АС и СТШ, а с другой - соответствует сейсмологическим данным о механизмах очагов землетрясений, полученным для коры Хубсугульской и Тункинской впадин [Melnikova et al., 2001]. По этим данным, в глубине впадин для десятка механизмов очагов землетрясений либо имеет место сброс (ось $P$ субвертикальна, а $T$ субгоризонтальна), либо сброс со сдвигом. В краевой зоне впадин наблюдаются механизмы как в виде взбросов и сдвигов, так и в виде сбросов, а также их сочетания. При этом определения антиподных типов механизмов очагов землетрясения (взброс и сброс) могут располагаться достаточно близко (5-10 км) друг от друга.

В работе [Melnikova et al., 2001], так же как и в работе [Parfeevets, San'kov, 2006], подобный факт объяснялся временными вариациями напряженного состояния. В отличие от палеостресс-реконструкции, где эти временные этапы были разделены отрезками в первые миллионы лет, вариации в современном поле напряжений связывали с периодом в первые десятки лет. Близкое по пространству сосуществование антиподных механизмов очагов говорит о высокой неоднородности поля напряжений в коре краевых частей рифтовых впадин и отражает смену ориентации главных осей напряже- 
ний от субвертикальной ориентации максимального сжатия в их осевой части до субгоризонтальной под горным обрамлением.

Данные о напряженном состоянии крупных складок [Gzovsky 1963; Marinin, 2013; Mileev, Rozanov, 1976] показывают возможность разного типа напряженного состояния в непосредственной близости от поверхности. Здесь обратим внимание на единый геодинамический тип напряженного состояния в антиклиналях и синклиналях складок для продольного сжатия и отличный от них, но тоже единый для поперечного изгиба (если базироваться на экспериментах - см. комментарий к исследованиям М.В. Гзовского). Если сюда еще добавить возможность влияния на современное напряженное состояние остаточных напряжений, возникающих в коре поднятий [Voight, 1966; Rebetsky, $2008 a, 2008 b, 2008 c]$, то приходим к пониманию возможности изменения напряженного состояния с глубиной. Такое изменение типа напряженного состояния прежде всего может иметь место в коре горных поднятий, в то время как кора впадин может в поле напряжений выглядеть более стабильной.

Данные GPS-геодезии, пересчитанные в поле деформаций, не противоречат, а данные горного дела в виде результатов замеров напряжений insitu в шахтах и выработках полностью подтверждают результаты тектонофизической реконструкции природных напряжений.

О горизонтальных напряжениях. Как следует из in-situ данных, на больших глубинах (около 3 км и, возможно, более) независимо от того, было ли в верхних горизонтах горизонтальное сжатие выше вертикального или нет, соотношение $\sigma_{H} / \sigma_{z}$ стремится к 0.8-1.0. Это крайне важное наблюдение, которое требует своего объяснения. Во всяком случае, в верхней части коры (глубины менее 2-3 км), где согласно (см. рис. 3, б) горизонтальные напряжения сжатия могут превышать литостатическое давление, располагаются наименее прочные породы, имеющие к тому же наименьшие значения упругих модулей. Здесь существует меньший уровень всестороннего давления, определяющий и невысокий предел трещинной текучести (прочности, обеспеченной трением на поверхности трещин). Из-за этого породы самой верхней части коры не способны накопить большую упругую деформацию и затем передать ее на большие расстояния, как этого требуют постулаты тектоники плит.

Если исходить из того, что до начала латерального сжатия кора будущих орогенов имела платформенный режим, то можно предположить, что в это время ее напряженное состояние было полностью обусловлено только влиянием силы тяжести. В этом случае в вертикальном направлении будут действовать напряжения максимального сжатия, равные весу вышележащих горных пород $\left(\sigma_{3}=\sigma_{z}=-\gamma H\right)$ [Dinnik, 1926], а сжимающие напряжения в горизонтальном направлении $\left(\sigma_{x}=\sigma_{y}\right)$ будут меньше по абсолютной величине (напряжения сжатия принимают отрицательные значения). Подобный тип напряженного состояния в геодинамике и тектонофизике принято именовать режимом горизонтального растяжения. Попутно заметим, что действие только массовых сил в платформенном режиме предполагает отсутствие латеральных перемещений горных масс, т.е. деформирование в стесненных условиях [Dinnik, 1926; Rebetsky, 2008a, 2008b, 2008c]. Таким образом, в данном случае нагружения деформаций горизонтального растяжения реально не происходит, но тип напряженного состояния отвечает ориентации в горизонтальном направлении главного напряжения максимального девиаторного растяжения (полное напряжение является наименьшим сжатием)

Оценим в рамках идей работы [Sibson, 1974] величины напряжений, отвечающие как стадии начального чисто гравитационного напряженного состояния, так и стадии, в которой дополнительное горизонтальное сжатие привело к формированию режима горизонтального сжатия.

Из данных in-situ следует, что на больших глубинах отношение $\sigma_{H} / \sigma_{z}$ стремится к 0.8-1.0 (см. рис. 3 б). Эти значения отвечают режиму горизонтального растяжения, возникающему только от действия массовых сил. Будем, следуя этим результатам, полагать, что на глубинах более 5 км отношение $\sigma_{H} / \sigma_{z}=0.8$. Отсюда следует, что отношение тектонического давления $p$ к литостатическому $p_{l t}=-\sigma_{z}=\gamma H$ составит около 0.87, а $\tau / p_{l t}=0.1$. Если положить $\sigma_{H} / \sigma_{z}=0.9$, то отношение $p / p_{l t}$ увеличится до значений 0.93 , а $\tau / p_{l t}$ снизится до 0.035 .

Поскольку на больших глубинах (средняя кора) напряженное состояние отвечает стадии катакластического течения, т.е. формированию необратимых деформаций за счет трещинного течения [Rebetsky, 2003, 2007], эти напряжения должны удовлетворять предельному соотношению текучести, которое можно записать в виде закона КулонаMopa [Jager, 1962]:

$$
\begin{aligned}
& \tau-\left(p-p_{f l}\right) k_{f} \leq \tau_{f} \\
& \tau=\left(\sigma_{x}-\sigma_{z}\right) / 2 \\
& p=-\left(\sigma_{x}+\sigma_{y}+\sigma_{z}\right) / 3,
\end{aligned}
$$$$
\text { при }
$$

и

где $p_{f l}$ - флюидное давление, а $\tau_{f}$ и $k_{f}$ - предел внутренней прочности пород и коэффициент внут- 
реннего трения соответственно.

Из условия (3) можно оценить уровень флюидного давления, при котором для данного уровня напряжений выполняется предельное соотношение (равенство). При расчетах положим $\tau_{f} / p_{l t} \approx 0$ (для глубин более 5 км), а $k_{f}=0.6$ [Byerlee, 1978]. Таким образом, из (1) получим $\lambda=p_{f l} / p_{l t} \approx 0.7$ (если $\sigma_{H} / \sigma_{z}=0.9$, то $\lambda=0.86$ ). Это значение флюидного давления хорошо согласуется с результатами реконструкции напряжений для орогенов СТШ и AC [Rebetsky, Sycheva, 2008; Rebetsky et al., 2009, 2010].

Таким образом, если принять, что кора находится в условиях действия начального гравитационного состояния при выполнении соотношения $\sigma_{H} / \sigma_{z}=0.8$ (данные in-situ), то горизонтальное сжатие на глубине 25 км (половина средней мощности коры АС и СТШ) будет меньше литостатики на 1.3 кбар.

Попробуем теперь оценить дополнительные напряжения латерального сжатия, которые следует добавить к напряженному состоянию, вызванному массовыми силами, чтобы произошла не только смена ориентации максимального сжатия $\left(\sigma_{x}=\sigma_{3}\right)$, но в новом геодинамическом режиме также был достигнуто предельное состояние (3). Заметим, что в зависимости от соотношения второго главного напряжения, действующего в горизонтальном направлении $\left(\sigma_{y}\right)$, и вертикального напряжения $\sigma_{z}$ в новом состоянии будет иметь место геодинамический режим либо горизонтального сжатия, либо горизонтального сдвига. Положим, что так же, как и на стадии действия только массовых сил, $\tau_{f} /\left|\sigma_{z}\right| \approx 0$, а $\lambda=0.7$. Будем также считать, что на этой стадии в другом латеральном направлении напряжения $\left(\sigma_{y}\right)$ равны вертикальным напряжениям $\left(\sigma_{z}\right)$. Это допущение хорошо согласуется с наблюдаемым из результатов реконструкции фактом сочетания в горно-складчатых орогенах режимов горизонтального сдвига и сжатия. Если уровень сжимающих напряжений $\sigma_{y}$ в каких-то участках коры немного превысит $\sigma_{z}$, то эти участки будут находиться в режиме горизонтального сжатия, а если будет несколько ниже $\sigma_{z}$, то здесь будет режим горизонтального сдвига.

В такой постановке из (3) получим, что $\sigma_{H} / \sigma_{z}=1.6$, т.е. сжимающее напряжение в направлении активного деформирующего усилия возрастает вдвое в сравнении с начальным этапом, когда действовали лишь одни массовые силы. В этом случае отношение $p / p_{l t}$ составит около 1.2 , т.е. оно увеличивается на $38 \%$, а $\tau / p_{l t}$ будет около 0.3 , т.е. оно увеличивается втрое в сравнении с начальным состоянием. Выполненные расчеты показывают, что если для чисто гравитационного напряженного состояния на глубине 25 км горизонтальные сжимающие напряжения составляют около 5.4 кбар, то на стадии горизонтального сжатия, достигающего предельного состояния (3), эти напряжения составят уже около 10.8 кбар. Таким образом, для перехода от чисто гравитационного состояния, которому отвечает геодинамический режим горизонтального растяжения, к режиму горизонтального сжатия необходимо приложить дополнительное горизонтальное сжимающее напряжение около 5.4 кбар.

Если принять значение длительного (геологическое время) модуля упругости массивов горных пород $E$ равным 50 кбар (это значение почти на порядок ниже значений динамического модуля упругости, определяемого по скоростям сейсмических волн), то деформации горизонтального укорочения $\varepsilon_{x x}$ должны составить около $10 \%$, что при скорости горизонтальных деформаций в $10^{-8}$ год $^{-1}$ потребует 10 млн лет. Отметим, что при оценке длительных деформаций для массивов следует использовать значения длительного модуля упругости, которые могут быть на порядок ниже, чем значения модуля упругости образцов или модуля упругости, получаемые по данным о скоростях упругих волн [Vlasov, Merzlyakov, 2009].

Заметим, что в период смены геодинамического типа напряженного состояния напряженное состояние коры ниже предельного, отвечающего формированию или активизации крупных разрывных смещений (масштаба коры). В этот период латеральное сокращение коры идет только за счет упругих деформаций, которые достаточно малы (2-3 \%). Дальнейшее сокращение коры, необходимое для увеличения ее мощности на $30-40 \%$ (от 45 до 55-60 км), потребует еще 20-25 млн лет (для вязкости пород коры $10^{23}$ Па·c). Заметим, что в приведенных оценках использовались скорости региональных деформаций, измеряемые сегодня спутниковой геодезией (самые высокие, по В.Г.Трифонову [Trifonov et al., 2012], за все последние 50 млн лет).

Из приведенного анализа следует, что режим деформирования коры, связанный с чисто гравитационным напряженным состоянием, отличается от режима деформирования, вызываемого внешним боковым давлением, не только ориентациями главных напряжений, но и величиной тектонического давления. Для режима горизонтального сжатия оно значительно больше.

\section{7. ЗАКЛЮЧЕНИЕ}

Результаты проведенных исследований показали, что состояние коры впадин и поднятий в виде 
отдельных хребтов и их групп в областях внутриконтинентальных орогенов является антиподным. Разные типы исследований, обзор которых был сделан в статье, показали, что в коре активно растущих поднятий и прогибающихся впадин разный геодинамический тип напряженного состояния. В приложении к орогенам это означает, что в коре хребтов максимальное сжатие преимущественно субгоризонтально, а в коре межгорных или крупных внутригорных впадин в субгоризонтальном направлении преимущественно ориентирована ось минимального сжимающего напряжения (максимального девиаторного растяжения). Уровень всестороннего сжатия в коре развивающегося поднятия выше, чем в соседних участках коры.

Выполненные оценки величины дополнительных горизонтальных напряжений, необходимых для смены геодинамического типа напряженного состояния горизонтального растяжения на горизонтальное сжатие, дают значение около 5.4 кбар. Для скоростей латеральных деформаций, замеряемых сегодня GPS-геодезией, потребуется до 10 млн лет для того, чтобы латеральные деформации создали подобный уровень напряжений. При значениях напряжений, отвечающих пределу текучести пород для геодинамического типа напряженного состояния горизонтального сжатия, необходимо 20-25 млн лет для создания утолщенной коры в 55-60 км.

Таким образом, в орогенах часто соседствуют участки коры с двумя различающимися состояниями, в одном из которых величина всестороннего сжатия (кора хребтов и поднятий) существенно превышает уровень всестороннего сжатия соседней впадины. Подобная ситуация для выполнения механического равновесия требует появления вблизи границы Мохо на горизонтальных площадках поддвиговых касательных напряжений, ориентированных в разные стороны от впадины (для площадок с нормалями, направленными к центру земли). Поскольку в орогенах впадины и горные поднятия достаточно мозаично распределены, это должно приводить также к мозаичности в ориентации таких касательных напряжений. Результаты тектонофизических реконструкций напряжений [Rebetsky et al., 2012, 2013; Rebetsky, Alekseev, 2014] показали, что наибольшая вариабильность и мозаичность в распределении ориентации поддвиговых касательных напряжений наблюдается именно там, где имеются крупные впадины.

Возвращаясь к проблеме, обозначенной во введении, еще раз отметим, что задача геомеханического моделирования процесса горообразования не должна заключаться в простой попытке получить деформированную структуру кровли и подошвы коры, похожую на природную. Необходимо, чтобы и закономерности изменения геодинамического типа напряженного состояния, уровня всестороннего давления, ориентации осей поддвиговых касательных напряжений в областях выгибов и прогибов поверхности модели соответствовали тому, что получено для коры соответственно поднятий и впадин по результатам тектонофизической реконструкции напряжений. Опыт моделирования показывает, что на подбор условий нагружения, которые могут быть связаны как с внешними, так и с внутренними источниками энергии, наибольшее влияние оказывают именно требования подобия по напряженному состоянию.

Соотношение амплитуд рельефа кровли и подошвы коры, вносящее наибольший вклад в гравитационные аномалии, следует также рассматривать как ограничение на выбор механизма нагружения.

\section{8. БЛАГОДАРНОСТИ}

Работа выполнена при поддержке программы № 6 ОНЗ РАН и в рамках бюджетной тематики лаборатории тектонофизики ИФЗ РАН.

\section{9. ЛИТЕРАTУРА / REFERENCES}

Abdrakhmatov K.E., Tsurkov V.E., 1991. Modern movement of the Earth's crust. In: N.P. Laverov (Ed.), Modern geodynamics of the lithosphere of Tien Shan. Nauka, Moscow, p. 75-77 (in Russian) [Абдрахматов К.Е., Цурков В.Е. Современные движения поверхности земной коры // Современная геодинамика литосферы Тянь-Шаня / Ред. Н.П. Лаверов. М.: Наука, 1991. С. 75-77].

Abdrakhmatov K.E., Weldon R., Thompson S., Burbank D., Rubin C., Miller M., Molnar P., 2001. Origin, direction, and rate of modern compression in the central Tien Shan, Kyrgyzstan. Geologiya i Geofizika (Russian Geology and Geophysics) 42 (10), 1585-1609.

Angelier J.T., Mechler P., 1977. Sur une methode graphique de recherche des contraintes principales egalement utilisables en tectonique et en seismologie: la methode des diedres droits. Bulletin de la Société géologique de France (Series 7) 19 (6), 1309-1318. http://dx.doi.org/10.2113/gssgfbull.S7-XIX.6.1309.

Belousov V.V., 1976. Geotectonics. Moscow State University, Moscow, 328 p. (in Russian) [Белоусов В.B. Геотектоника. М.: Московский государственный университет, 1976. 328 с.]. 
Bondarenko P.M., Luchitsky I.V., 1985. Shear faults and cleavage zones in tectonic stress fields. In: I.V. Luchitsky, P.M. Bondarenko (Ed.), Experimental tectonics in theoretical and applied geology. Nauka, Moscow, p. 159-182 (in Russian] [Бондаренко П.М., Лучищкий И.В. Сдвиги и зоны скалывания в тектонических полях напряжений // Экспериментальная тектоника в теоретической и прикладной геологии / Ред. И.В. Лучицкий, П.М. Бондаренко. М.: Наука, 1985. С. 159-182].

Bornyakov S.A., 1988. The evolution dynamics of destructive zones of interplate boundaries (the results of modeling). Geologiya i Geofizika (Russian Geology and Geophysics) (6), 3-10 (in Russian) [Борняков C.А. Динамика развития деструктивных зон межплитных границ (результаты моделирования) // Геология и геофизика. 1988. № 6. C. 3-10].

Brady B., Brown E., 2004. Rock Mechanics for Underground Mining. Third edition. Springer, Dordrecht, 688 p.

Burtman V.S., 2012. Tian Shan and High Asia: Geodynamics in the Cenozoic. GEOS, Moscow, 188 p. (in Russian) [Буртман В.С. Тянь-Шань и Высокая Азия: геодинамика в кайнозое. М.: ГЕОС, 2012. 188 с.].

Buslov M.M., Klerkx J., Abdrakhmatov K., Delvaux D., Batalev V.Yu., Kuchai O.A., Dehandschutter B., Miraliev A., 2003. Recent strike-slip deformation of the northern Tien-Shan. In: F. Storti, R.F. Holdsworth, F. Salvini (Eds.), Intraplate strike-slip deformation belts. Geological Society, London, Special Publications, vol. 201, p. 53-64. http://dx.doi.org/ 10.1144/GSL.SP.2003.210.01.04.

Byerlee J.D., 1978. Friction of rocks. Pure and Applied Geophysics 116 (4), 615-626. http://dx.doi.org/10.1007/ BF00876528.

Demin S.S., Nikitin L.V., 1991. Conditions of seismogenic activation of shear tectonic faults. Doklady AN SSSR 321 (5), 932-937 (in Russian) [Демин С.С., Никитин Л.В. Условия оживления сейсмогенности сдвиговых тектонических разломов // Доклады АН СССР. 1991. Т. 321. № 5. С. 932-937].

Dewey J.F., Bird J.M., 1970. Mountain belts and the new global tectonics. Journal of Geophysical Research 75 (14), 2625-2647. http://dx.doi.org/10.1029/JB075i014p02625.

Dinnik A.N., 1926. On the pressure of rocks and bolting per round mine. Inzhenerny Rabotnik (Engineering Worker) (3), 1-12 (in Russian) [Динник A.Н. О давлении горных пород и расчете крепи круглой шахты // Инженерный работник. 1926. № 3. С. 1-12].

Geptner T.M., 1970. Modeling of cleavage fractures in conditions of major deformation. Bulletin of the Moscow State University. Geological Series (4), 81-89 (in Russian) [Гептнер T.М. Моделирование трещин скалывания в условиях больших деформаций // Вестник Московского государственного университета. Серия геологическая. 1970. № 4. C. 81-89].

Goodman R.E., 1989. Introduction to Rock Mechanics. Second edition. Wiley, New York, 562 p.

Grigoriev A.S., 1991. Mathematical modeling in tectonophysics. In: A.V. Chekunov (Ed.), Experimental tectonics and field tectonophysics. Naukova Dumka, Kiev, p. 21-29 (in Russian) [Григорьев А.С. О математическом моделировании в тектонофизике // Экспериментальная тектоника и полевая тектонофизика / Ред. А.В. Чекунов. Киев: Наукова думка, 1991. С. 21-29].

Grigoriev A.S., Mikhailova A.V., 1985. The combination of theoretical and experimental methods for the study of the processes of tectonic structures formation. In: I.V. Luchitskii, P.M. Bondarenko (Eds.), Experimental tectonics in theoretical and applied geology. Nauka, Moscow, p. 131-146 (in Russian) [Григорьев А.С., Михайлова А.В. Сочетание теоретического и экспериментального методов при исследовании процессов образования тектонических структур // Экспериментальная тектоника в теоретической и прикладной геологии / Ред. И.В. Лучицкий, П.М. Бондаренко. М.: Наука, 1985. С. 131-146].

Grigoriev A.S., Volovich I.M., Mikhailova A.V., Rebetsky Yu.L., 1989. Problem of kinematics and stress state of layer with mixed boundary conditions in relation to interpretation of recent movements in platform regions. Izvestia AN SSSR. Seriya Fizika Zemli (7), 38-54 (in Russian) [Григорьев А.С., Волович И.М., Михайлова А.В., Ребецкий Ю.Л. Задача о кинематике и напряженном состоянии слоя при смешанных краевых условиях в связи с интерпретацией современных движений в платформенных областях // Известия АН СССР. Серия Физика Земли. 1989. № 7. C. 38-54].

Guseva T.V., Lukk A.A., Trapeznikov Yu.A., Shevchenko A.I., 1993. Geodynamics of the Garm polygon in Tajikistan according to light-distance measurement results. Geotektonika (Geotectonics) (3), 47-54 (in Russian) [Гусева T.В., Лукк А.А., Трапезников Ю.А., Шевченко А.И. Геодинамика территории Гармского полигона (Таджикистан) по результатам светодальномерных наблюдений // Геотектоника. 1993. № 3. С. 47-54].

Guterman V.G., 1987. Mechanisms of Tectogenesis (Based on Tectonophysical Modeling). Naukova Dumka, Kiev, 172 p. (in Russian) [Гутерман В.Г. Механизмы тектогенеза (по результатам тектонофизического моделирования). Киев: Наукова Думка, 1987. 172 с.].

Gzovsky M.V., 1954a. Modeling of tectonic stress fields and ruptures. Izvestiya AN SSSR. Seriya geofizicheskaya (6), 527-545 (in Russian) [Гзовский М.В. Моделирование тектонических полей напряжений и разрывов // Известия АН СССР. Серия геофизическая. 1954. № 6. С. 527-545].

Gzovsky M.V., 1954b. Tectonic stress field. Izvestiya AN SSSR. Seriya geofizicheskaya (5), 390-410 (in Russian) [Гзовский М.В. Тектонические поля напряжений // Известия АН СССР. Серия геофизическая. 1954. № 5. C. 390-410]. 
Gzovsky M.V., 1959. The Main Issues of Tectonophysics and Tectonics of Baydzhansaysky Anticlinorium. Parts I and II. Publishing House of the USSR Academy of Sciences, Moscow, 256 p. (in Russian) [Гзовский М.В. Основные вопросы тектонофизики и тектоника Байджансайского антиклинория. Ч. I, II. М.: Изд-во АН СССР, 1959. 256 с.].

Gzovsky M.V., 1963. The Main Issues of Tectonophysics and Tectonics of Baydzhansaysky Anticlinorium. Parts III and IV. Publishing House of the USSR Academy of Sciences, Moscow, 544 p. (in Russian) [Гзовский М.В. Основные вопросы тектонофизики и тектоника Байджансайского антиклинория. Ч. III, IV. М.: Изд-во АН CCCP, 1963. 544 c.].

Gzovsky M.V., 1975. Fundamentals of Tectonophysics. Nauka, Moscow, 535 p. (in Russian) [Гзовский М.В. Основы тектонофизики. М.: Наука, 1975. 535 с.].

Haxby W.F., Turcotte D.L., 1976. Stress induced by the addition or removal of overburden and associated thermal effect. Geology 4 (3), 181-184. http://dx.doi.org/10.1130/0091-7613(1976)4<181:SIBTA0>2.0.C0;2.

Heim A., 1878. Untersuchungen über den Mechanismus der Gebirgsbildung: im Anschluss an die geologische Monographie der Tödi-Windgällen-Gruppe. B. Schwabe, Basel, 346 p.

Jager J.C., 1962. Elasticity Fracture and Flow. Methuen \& Co. Ltd., London, 208 p.

Jager C., 1972. Rock Mechanics and Engineering. Cambridge University Press, Cambridge, 417 p.

Karpinsky A.P., 1919. On the tectonics of European Russia. Izvestiya Akademii Nauk (Seriya VI) 13 (12-15), 573-590 (in Russian) [Карпинский А.П. К тектонике Европейской России // Известия Академии наук. VI серия. 1919. T. 13. № 12-15. C. 573-590].

Knauf V.I., 1976. Tectonic zoning of the North Tien Shan. Geotektonika (Geotectonics) (5), 27-32 (in Russian) [Кнау $\varnothing$ B.И. Тектоническое районирование Северного Тянь-Шаня // Геотектоника. 1976. № 5. С. 27-32].

Kostyuk A.D., 2009. The Study of Recent Crustal Deformation of the Northern Tien Shan Based on Earthquake Focal Mechanisms and Space Geodesy Data. PhD Thesis in Physics and Mathematics. Publishing House of Bishkek NS RAS, Bishkek, 23 p. (in Russian) [Костюк А.Д. Исследование современных деформаций земной коры Северного Тянь-Шаня по данным механизмов очагов землетрясений и космической геодезии: Автореф. дис. ... канд. физ.-мат. наук. Бишкек: НС РАН, 2009. 23 с.].

Kostyuk A.D., Sycheva N.A., Yunga S.L., Bogomolov L.M., Yagi Y., 2010. Deformation of the Earth's crust in the Northern Tien Shan according to the earthquake focal data and satellite geodesy. Izvestiya, Physics of the Solid Earth 46 (3), 230-243. http://dx.doi.org/10.1134/S1069351310030055.

Kosygin Yu.A., Magnitsky V.A., 1948. On the possible forms of geometric and mechanical connection of primary vertical movements, magmatism and folding. Bulletin of Moscow Society of Naturalists (3), 158-166 (in Russian) [Косыгин Ю.А., Магницкий B.A. О возможных формах геометрической и механической связи первичных вертикальных движений, магматизма и складчатости // Бюллетень Московского общества испытателей природы. 1948. № 3. С. 158-166].

Kozyrev A.A., Savchenko S.N., 2000. The Eurasia lithospheric plate horizontal tectonic stress modeling. In: S.A. Yufin (Ed.), Geoecology and Computers. Taylor \& Francis, Brookfield, p. 432-435.

Krupennikov G.A., Filatov N.A., Amusin B.Z., Barkovsky V.M., 1972. Distribution of Stresses in Natural Massifs. Nedra, Moscow, 143 p. (in Russian) [Крупенников Г.А., Филатов Н.А., Амусин Б.З., Барковский В.М. Распределение напряжений в природных массивах. М.: Недра, 1972. 143 с.].

Kurlenya M.V. (Ed.), 1996. Rock Pressure Control in Tectonically Stressed Massifs. Part 1. Publishing House of KSC RAS, Apatity, 160 p. (in Russian) [Управление горным давлением в тектонически напряженных массивах / Ред. М.В. Курленя. Апатиты: КНЦ РАН, 1996. Ч. 1. 160 с.].

Kuzikov S.I., Barkalova T.S., Kostyuk A.D., 2009. Temporary rows and stability of linear velocities within the Central Asian GPS network. In: Geodynamics of intracontinental orogens and geological problems. Proceedings of the 4th International Symposium, 15-20 June 2008. Issue 4. NS RAS, Moscow-Bishkek, p. 104-108 (in Russian) [Кузиков С.И., Баркалова Т.С., Костюк А.Д. Временные ряды и устойчивость линейных скоростей в пределах Центрально-Азиатской GPS сети // Геодинамика внутриконтинентальных орогенов и геологические проблемы: Материалы IV международного симпозиума 15-20 июня 2008 г. Вып. 4. Москва-Бишкек: НС РАН, 2009. C. 104-108].

Laverov N.P. (Ed.), 2005. Contemporary Geodynamics of the Intracontinental Collision Orogeny (Central Asia). Nauchny Mir, Moscow, 400 p. (in Russian) [Современная геодинамика внутриконтинентального коллизионного горообразования (Центральная Азия) / Ред. Н.П. Лаверов. М.: Научный Мир, 2005. 400 с.].

Leonov Yu.G., 1995. The stresses in the lithosphere and intraplate tectonics. Geotektonika (Geotectonics) (6), 3-21 (in Russian) [Леонов Ю.Г. Напряжения в литосфере и внутриплитная тектоника // Геотектоника. 1995. № 6. C. 3-21].

Leonov Yu.G., 2009. On some peculiarities of geology at the present stage. In: The History of the Earth Sciences. IIET, Moscow, p. 9-27. (in Russian) [Леонов Ю.Г. О некоторых особенностях геологии на современном этапе // История наук о Земле. М.: ИИЕТ РАН, 2009. С. 9-27].

Liberman Yu.M., 1962. The natural stress state of rock massif. In: Trudy VNIIST. Issue 12. Moscow, p. 24-30 (in Russian) [Либерман Ю.М. Естественное напряженное состояние массива горных пород // Труды ВНИИСТ. Вып. 12. М., 1962. С. 24-30]. 
Lukk A.A., Leonova V.G., Shevchenko V.I., 2008. Seismotectonic characteristics of the northern flank and axial part of the Tajik Depression (the Garm Geodynamic Research Area). Izvestiya, Physics of the Solid Earth 44 (12), 965-1001. http://dx.doi.org/10.1134/S1069351308120021.

Magnitsky V.A., 1965. The Internal Structure and Physics of the Earth. Nedra, Moscow, 379 p. (in Russian) [Магницкий В.A. Внутреннее строение и физика Земли. М.: Недра, 1965. 379 с.].

Makarov V.I., 1977. The Neotectonic Structure of the Central Tien Shan. Nauka, Moscow, 171 p. (in Russian) [Макаров В.И. Новейшая тектоническая структура Центрального Тянь-Шаня. М.: Наука, 1977. 171 с.]

Makarov V.I., 1980. Nonconformities and phases of activation of tectonic movements (concerning the paleotectonic interpretation of nonconformities). In: A.V. Peive, Yu.G. Leonov (Ed.), Problems of global correlation of geological phenomena. Nauka, Moscow, p. 139-144 (in Russian) [Макаров В.И. Несогласия и фазы активизации тектонических движений (к палеотектонической интерпретации несогласий) // Проблемы глобальной корреляции геологических явлений / Ред. А.В. Пейве, Ю.Г. Леонов. М.: Наука, 1980. С. 139-144].

Makarov V.I., Alekseev D.V., Batalev V.Y., Bataleva E.A., Belyaev I.V., Bragin V.D., Dergunov N.T., Efimova N.N., Leonov M.G., Munirova L.M., Pavlenkin A.D., Roecker S., Roslov Yu.V., Rybin A.K., Shchelochkov G.G., 2010. Underthrusting of Tarim beneath the Tien Shan and deep structure of their junction zone: Main results of seismic experiment along MANAS Profile Kashgar-Song-Köl. Geotectonics 44 (2), 102-126. http://dx.doi.org/10.1134/S0016852110020020.

Makarov V.I., Rybin A.K., Matyukov V.E., Pushkarev P.Yu., Shcherbina F.A., 2011. Specific features of the deep structure of depression areas in the Central Tien Shan. Inzhenernye Izyskaniya (Engineering Surveys) (1), 42-51 (in Russian) [Макаров В.И., Рыбин А.К., Матюков В.Е., Пушкарев П.Ю., Щербина Ф.А. Особенности глубинной структуры депрессионных областей Центрального Тянь-Шаня // Инженерные изыскания. 2011. № 1. С. 42-51].

Marinin A.V., 2013. The tectonophysical researches of the Semisamskaya anticline (North-Western Caucasus fold and thrust belt). Geodynamics \& Tectonophysics 4 (4), 461-484 (in Russian) [Маринин А.В. Тектонофизические исследования Семисамской антиклинали (Северо-Западный Кавказ) // Геодинамика и тектонофизика. 2013. T. 4. № 4. C. 461-484]. http://dx.doi.org/10.5800/GT-2013-4-4-0113.

Markov G.A., 1972. The state of stresses in the Khibiny mines and its relation to recent tectonic movements of the crust. In: Yu.D. Boulanger, Yu.A. Meshcheryakov (Eds.), Studies of the structure and recent crustal movements at the Kola geophysical polygon (Results of International Geophysical Projects). Nauka, Moscow, p. 147-152 (in Russian) [Марков Г.А. Напряженность пород в Хибинских рудниках и ее связь с современными тектоническими движениями земной коры // Исследования строения и современных движений земной коры на Кольском геофизическом полигоне (результаты исследования по международным геофизическим проектам) / Ред. Ю.Д. Буланже, Ю.А. Мещеряков. М.: Наука, 1972. С. 147-152].

Markov G.A., 1977. Tectonic Stress and Confining Pressure in Mines in the Khibiny Massif. Nauka, Leningrad, 213 p. (in Russian] [Марков Г.А. Тектонические напряжения и горное давление в рудниках Хибинского массива. Л.: Наука, 1977. 213 с.].

Markov G.A., 1980. On propagation of horizontal tectonic stresses in the crust uplift zones. Inzhenernaya Geologiya (Engineering Geology) (1), 20-30 (in Russian) [Марков Г.A. О распространении горизонтальных тектонических напряжений в зонах поднятий земной коры // Инженерная геология. 1980. № 1. С. 20-30].

Markov G.A., 1985. The pattern of distribution of tectonic stresses in the upper crust. New data and practical applications. In: Correlation of geological and tectonic structures, properties, structural features of rocks and manifestations of excessive tension. Kola Branch of the USSR Acad. Sci., Apatity, p. 72-84 (in Russian) [Марков Г.А. Закономерность распределения тектонических напряжений в верхней части земной коры. Новые данные и практические приложения // Взаимосвязь геолого-тектонического строения, свойств, структурных особенностей пород и проявления избыточной напряженности. Апатиты: Кол. фил. АН СССР, 1985. С. 72-84].

Maslov L.A., Komova O.S., 1990. Numerical simulation of deep geodynamic processes in active margins. Izvestiya AN SSSR. Seriya Fizika Zemli (3), 51-63 (in Russian) [Маслов Л.А., Комова О.С. Численное моделирование глубинных геодинамических процессов в активных окраинах // Известия АН СССР. Серия Физика Земли. 1990. № 3. С. 51-63].

Melnikova V.I., Radziminovich N.A., Gileva N.A., Kurushin R.A., 2001. The mechanism and depths of earthquake foci in the south-western flank of the Baikal rift zone. In: Earth Sciences: Modern problems of seismology. Vuzovskaya Kniga, Moscow, p. 96-112 (in Russian) [Мельникова В.И., Радзиминович Н.А., Гилева Н.А., Курушин Р.А. Механизм и глубины очагов землетрясений юго-западного фланга Байкальской рифтовой зоны // Науки о Земле: современные проблемы сейсмологии. М.: Вузовская книга, 2001. С. 96-112].

Mikhailova A.V., 1971. The method for quantifying displacements, strains and stresses in opaque plastic models // Tectonophysics and Mechanical Properties of Rocks. Nauka, Moscow, p. 38-48 (in Russian) [Михайлова A.B. Meтодика количественной оценки перемещений, деформаций и напряжений в пластических непрозрачных моделях // Тектонофизика и механические свойства горных пород. М.: Наука, 1971. С. 38-48].

Mileev V.S., Rozanov S.B., 1976. Precambrian Geology and Tectonics of Central Kazakhstan. Moscow State University, Moscow, 363 p. (in Russian) [Милеев В.С., Розанов С.Б. Геология и тектоника докембрия Центрального Казахстана. М.: МГУ, 1976. 363 с.].

Molnar P., Tapponier P., 1975. Cenozoic tectonics of Asia: Effects of a continental collision. Science 189 (4201), 419-426. http://dx.doi.org/10.1126/science.189.4201.419. 
Nikolaevsky V.N., 1996. Geomechanics and Fluid Dynamics. Nedra, Moscow, 446 p. (in Russian) [Николаевский B.H. Геомеханика и флюидодинамика. М.: Недра, 1996. 446 с.].

Novikov I.S., 2004. Morphotectonics of the Altai Region. Geo Branch, Novosibirsk, 313 p. (in Russian) [Новиков И.C. Морфотектоника Алтая. Новосибирск: Изд-во СО РАН, филиал «Гео», 2004. 313 с.].

Osokina D.N., 1963. Plastic and Elastic Low-Module Optically Active Materials for Studies of Crustal Stresses by Simulation. Publishing House of the USSR Acad. Sci., Moscow, 196 p. (in Russian) [Осокина Д.Н. Пластичные и упругие низкомодульные оптически-активные материалы для исследования напряжений в земной коре методом моделирования. М.: Изд-во АН СССР, 1963. 196 с.].

Osokina D.N., 1987. The relationship between displacements along faults and tectonic stress fields, and destruction of massifs. In: Yu.D. Boulanger (Ed.), Crustal stress and strain fields. Nauka, Moscow, p. 120-135 (in Russian) [Ocoкина Д.Н. Взаимосвязь смещений по разрывам с тектоническими полями напряжений и некоторые вопросы разрушения горного массива // Поля напряжений и деформаций в земной коре / Ред. Ю.Д. Буланже. М.: Наука, 1987. С. 120-135].

Parfeevets A.V., San'kov V.A., 2006. Stress State of the Earth's Crust and Geodynamics of the Southwestern Part of the Baikal Rift System. Geo Academic Publishing House, Novosibirsk, 151 p. (in Russian) [Парфеевец А.В., Саньков B.A. Напряженное состояние земной коры и геодинамика юго-западной части Байкальской рифтовой системы. Новосибирск: Академическое изд-во «Гео», 2006. 151 с.].

Peive A.V., Kropotkin P.N., 1973. A new approach to crustal stress studies. In: The state of stresses of the Earth's Crust. Nauka, Moscow, p. 5-11 (in Russian) [Пейве А.В., Кропоткин П.Н. Новый подход к изучению напряжений в земной коре // Напряженное состояние земной коры. М.: Наука, 1973. С. 5-11].

Ponomarev V.S., 2007. Denudation and seismicity of the Earth's Crust. Doklady Earth Sciences 412 (1), 19-21. http://dx.doi.org/10.1134/S1028334X07010059.

Ponomarev V.S., 2008. Energy Capacity of Geological Environment. Nauka, Moscow, 378 p. (in Russian) [Пономарев В.С. Энергонасыщенность геологической среды. М.: Наука, 2008. 378 с.]

Rebetskii Yu.L., 2011. The influence of elastic compressibility of the mantle on thermal-gravitational convection: The convective instability of the gravitational stress pattern. Doklady Earth Sciences 440 (1), 1328-1333. http://dx.doi.org/10.1134/S1028334X11090212.

Rebetsky Yu.L., 1988. Stress state of layer with longitudinal shear. Izvestiya AN SSSR. Seriya Fizika Zemli (9), 29-35 (in Russian) [Ребецкий Ю.Л. Напряженное состояние слоя при продольном сдвиге // Известия АН СССР. Серия Физика Земли. 1988. № 9. С. 29-35].

Rebetsky Yu.L., 1997. Reconstruction of tectonic stresses and seismotectonic strains: Methodical fundamentals, current stress field of southeastern Asia and Oceania. Transactions (Doklady) of the Russian Academy of Sciences, Earth science sections 354 (4), 560-563.

Rebetsky Yu.L., 1999. Methods for reconstructing tectonic stresses and seismotectonic deformations based on the modern theory of plasticity. Doklady Earth Sciences 365A (3), 370-373.

Rebetsky Yu.L., 2003. The State of Stresses and Mechanical Properties of Natural Massifs According to Data on Earthquake Focal Mechanisms and Structural and Kinematic Characteristics of Fractures. Abstract of PhD Thesis (Physics and Mathematics). Publishing House of UIPE, Moscow, 56 p. (in Russian) [Ребецкий Ю.Л. Напряженнодеформированное состояние и механические свойства природных массивов по данным о механизмах очагов землетрясений и структурно-кинематическим характеристикам трещин: Автореф. дис. ... докт. физ.мат. наук. М.: Изд-во ОИФЗ, 2003. 56 с.].

Rebetsky Yu.L., 2007. Tectonic Stresses and Strength of Mountain Ranges. Akademkniga, Moscow, 406 p. (in Russian) [Ребецкий Ю.Л. Тектонические напряжения и прочность горных массивов. М.: Академкнига, 2007. 406 с.].

Rebetsky Yu.L., 2008a. Possible mechanism of horizontal compression stress generation in the Earth's crust. Doklady Earth Sciences 423 (2), 1448-1451. http://dx.doi.org/10.1134/S1028334X08090274.

Rebetsky Yu.L., 2008b. Mechanism of tectonic stress generation in the zones of high vertical movements. Fizicheskaya mezomekhanika (Physical Mesomechanics) 11 (1), 66-73 (in Russian) [Ребецкий Ю.Л. Механизм генерации тектонических напряжений в областях больших вертикальных движений // Физическая мезомеханика. 2008. T. 11. № 1. C. 66-73].

Rebetsky Yu.L., 2008c. The mechanism of generation of residual stresses and large horizontal compressive stresses in the crust of intraplate orogens. In: Problems of tectonophysics. The 40th anniversary of M.V. Gzovsky Laboratory of Tectonophysics, IPE RAS. Publishing House of IPE RAS, Moscow, p. 431-466 (in Russian) [Ребецкий Ю.Л. Механизм генерации остаточных напряжений и больших горизонтальных сжимающих напряжений в земной коре внутриплитовых орогенов // Проблемы тектонофизики. К 40-летию создания М.В. Гзовским лаборатории тектонофизики в ИФЗ РАН. М.: Изд-во ИФЗ РАН, 2008. С. 431-466].

Rebetsky Yu.L., Alekseev R.S., 2014. The field of recent tectonic stresses in Central and South-Eastern Asia. Geodynamics \& Tectonophysics 5 (1), 257-290 (in Russian) [Ребецкий Ю.Л., Алексеев Р.С. Тектоническое поле современных напряжений Средней и Юго-Восточной Азии // Геодинамика и тектонофизика. 2014. Т. 5. № 1. С. 257-290]. http://dx.doi.org/10.5800/GT-2014-5-1-0127. 
Rebetsky Yu.L., Kuchai O.A., Marinin A.V., 2007. The state of crustal stresses in Altai and Sayan regions before the Chuya earthquake of 2003. In: Problems of modern seismology and geodynamics of Central Asia. Materials of the AllRussia Conference with International Participation (18-24 September 2007, IEC SB RAS, Irkutsk). Publishing House of IEC SB RAS, Irkutsk, p. 106-111 (in Russian) [Ребецкий Ю.Л., Кучай О.А., Маринин А.В. Напряженное состояние земной коры Алтая и Саян до Чуйского землетрясения 2003 г. // Проблемы современной сейсмологии и геодинамики Центральной Азии: Материалы Всероссийского совещания с международным участием (18-24 сентября 2007 г., ИЗК СО РАН, г. Иркутск). Иркутск: ИЗК СО РАН, 2007. С. 106-111].

Rebetsky Yu.L., Kuchai O.A., Marinin A.V., 2008. The state of crustal stresses in the Altai-Sayan folded region before the Chuya (Altai) earthquake. In: Problems of tectonophysics of Earthquakes. The 40th anniversary of M.V. Gzovsky Laboratory of Tectonophysics, IPE RAS. Publishing House of IPE RAS, Moscow, p. 245-299 (in Russian) [Peбецкий Ю.Л., Кучай О.А., Маринин А.В. Напряженное состояние земной коры Алтае-Саянской складчатой области перед Чуйским (Алтайским) землетрясением // Проблемы тектонофизики. К 40-летию создания М.В. Гзовским лаборатории тектонофизики в ИФЗ РАН. М.: Изд-во ИФЗ РАН, 2008. С. 245-299].

Rebetsky Yu.L., Kuchai O.A., Marinin A.V., 2013. Stress state and deformation of the Earth's crust in the Altai-Sayan mountain region. Russian Geology and Geophysics 54 (2), 206-222. http://dx.doi.org/10.1016/j.rgg.2013.01.011.

Rebetsky Yu.L., Kuchai O.A., Sycheva N.A., 2009. The method of cataclastic analysis of faults and results of calculations of the recent state of crustal stress near plate boundaries and in intraplate mountain-folded orogens. In: Tectonophysics and topical issues of the Earth Sciences. The 40th anniversary of M.V. Gzovsky Laboratory of Tectonophysics, IPE RAS. Proceedings of the All-Russia Conference (13-17 October 2008). V. 1. Publishing House of IPE RAS, Moscow, p. 340-366 (in Russian) [Ребецкий Ю.Л., Кучай O.A., Сычева Н.А. Метод катакластического анализа разрывных нарушений и результаты расчетов современного напряженного состояния в коре вблизи границ плит и для внутриплитных горно-складчатых орогенов // Тектонофизика и актуальные вопросы наук о Земле. К 40-летию создания М.В. Гзовским лаборатории тектонофизики в ИФЗ РАН: Материалы Всероссийской конференции (13-17 октября 2008 г.). М.: Изд-во ИФЗ РАН, 2009. Т. 1. С. 340-366].

Rebetsky Yu.L., Mikhailova A.V., 2014. Deep heterogeneity of the stress state in the horizontal shear zones. Izvestiya, Physics of the Solid Earth 50 (6), 824-838. http://dx.doi.org/10.1134/S1069351314060068.

Rebetsky Yu.L., Sycheva N.A., 2008. Contemporary stress field of the Central Tien Shan. In: Relationship between the surface and deep structures of the Earth's crust. Proceedings of the 14th International Conference, Petrozavodsk (27-31 October 2008). V. 2. Publishing House of KSC RAS, Petrozavodsk, p. 146-150 (in Russian) [Ребецкий Ю.Л., Сычева Н.A. Современное поле напряжений Центрального Тянь-Шаня // Связь поверхностных структур земной коры с глубинными: Материалы 14-ой международной конференции, г. Петрозаводск (27-31 октября 2008 г.). Петрозаводск: Изд-во КНЦ РАН, 2008. Ч. 2. С. 146-150].

Rebetsky Yu.L., Sycheva N.A., Kuchay O.A., Tatevosian R.E., 2012. Development of inversion methods on fault slip data. Stress state in orogenes of the Central Asia. Tectonophysics 581, 114-131. http://dx.doi.org/10.1016/j.tecto.2012. 09.027.

Rebetsky Yu.L., Sycheva N.A., Kuzikov S.I., Kostyuk A.N., 2010. Tectonic stresses, seismotectonic and general tectonic crustal deformation of the Central Tien Shan. In: Problems of seismology in Uzbekistan. No. 7. Proceedings of the International Conference on modern problems of seismology, hydrogeology and engineering geology. V. 1. Publishing House of the National University of Uzbekistan, Tashkent, p. 268-274 (in Russian] [Ребецкий Ю.Л., Сычева Н.А., Кузиков С.И., Костюк А.Н. Тектонические напряжения, сейсмотектонические и общие тектонические деформации земной коры Центрального Тянь-Шаня // Проблемы сейсмологии в Узбекистане (№ 7): Материалы международной конференции «Современные проблемы сейсмологии, гидрогеологии и инженерной геологии». Ташкент: Изд. Нац. унив. Узб., 2010. Т. 1. С. 268-274].

Ruzhich V.V., 1978. On the combination of extension and compression stresses in the Baikal rift. In: N.A. Logachev (Ed.), Tectonics and Seismicity of Continental Rift Zones. Nauka, Moscow, p. 27-32 (in Russian) [Ружич B.В. O coчетании напряжений растяжения и сжатия в Байкальском рифте // Тектоника и сейсмичность континентальных рифтовых зон / Ред. Н.А. Логачев. М.: Наука, 1978. С. 27-32].

Ruzhich V.V., Khil'ko S.A., 1985. Some issues of modern and contemporary geodynamics of Prekhubsugul region. In: Proceedings of the International Conference on Results of the Soviet-Mongolian Khubsugul Expedition. Irkutsk, p. 20-21 (in Russian) [Ружич В.В., Хилько С.A. Некоторые вопросы новейшей и современной геодинамики Прихубсугулья // Труды Международной конференции по результатам работы Советско-монгольской комплексной Хубсугульской экспедиции. Иркутск, 1985. С. 20-21].

Ruzhich V.V., Sherman S.I., Tarasevich S.I., 1972. New data on the thrusts in the south-western part of the Baikal rift zone. Doklady AN SSSR 205 (4), 920-923 (in Russian) [Ружич В.В., Шерман С.И., Тарасевич С.И. Новые данные о надвигах в юго-западной части Байкальской рифтовой зоны // Доклады АН СССР. 1972. Т. 205. № 4. C. 920-923].

San'kov V.A., Parfeevets A.V., Lukhnev A.V., Miroshnichenko A.I., Ashurkov S.V., 2011. Late Cenozoic geodynamics and mechanical coupling of crustal and upper mantle deformations in the Mongolia-Siberia mobile area. Geotectonics 45 (5), 378-393. http://dx.doi.org/10.1134/S0016852111050049.

Seminsky K. Zh., 1991. Spatial and temporal relationships between tectonic faults in discontinuous zones. Geologiya $i$ Geofizika (Russian Geology and Geophysics) (3), 74-84 (in Russian) [Семинский К.Ж. Пространственновременные взаимоотношения между тектоническими нарушениями в разрывных зонах // Геология и геофизика. 1991. № 3. С. 74-84]. 
Sherman S.I., Dneprovsky Yu.I., 1989. Crustal Stress Field and Geological and Structural Methods of Studies. Nauka, Novosibirsk, 158 p. (in Russian] [Шерман С.И., Днепровский Ю.И. Поля напряжений земной коры и структурно-геологические методы их изучения. Новосибирск: Наука, 1989. 158 с.].

Sibson R.H., 1974. Frictional constraints on thrust, wrench and normal faults. Nature 249 (5457), 542-544. http://dx.doi.org/10.1038/249542a0.

Stefanov Yu.P., Bakeev R.A., Smolin I.Yu., 2009. Patterns of deformation localization in horizontal layers of a medium at shear displacement of the base. Fizicheskaya mezomekhanika (Physical Mesomechanics) 12 (1), 83-88 (in Russian) [Стефанов Ю.П., Бакеев Р.А., Смолин И.Ю. О закономерностях локализации деформации в горизонтальных слоях среды при разрывном сдвиговом смещении основания // Физическая мезомеханика. 2009. Т. 12 . № 1. С. 83-88].

Stoyanov S.S., 1979. Mechanism of Deformation in Fault Zones. Nedra, Moscow, 144 p. (in Russian) [Стоянов C.C. Механизм деформирования разрывных зон. М.: Недра, 1979. 144 с.].

Tikhomirov A.V., Smirnov A.L., Pil'guk O.D., Bakulina M.P., 2001. Monitoring of deformation processes on the Almaty prognostic test ground by tiltmeters and extensometers. Geologiya i Geofizika (Russian Geology and Geophysics) 42 (10), 1659-1666.

Timofeev V.Yu., 2012. Summary of results of long-term deformographic and GPS observations in intraplate regions In: Proceedings of the Third Tectonophysical Conference "Tectonophysics and topical issues of Earth Sciences" (Moscow, 8-12 October 2012). Publishing House of IPE RAS, Moscow, p. 241-244 (in Russian) [Тимофеев В.Ю. Обобщение результатов долговременных деформографических и GPS наблюдений для внутриплитных областей // Материалы Третьей тектонофизической конференции «Тектонофизика и актуальные вопросы наук о Земле» (г. Москва, 8-12 октября 2012 г.). М.: Изд-во ИФЗ РАН, 2012. С. 241-244].

Trifonov V.G., Ivanova T.P., Bachmanov D.M., 2012. Evolution of the central Alpine-Himalayan belt in the Late Cenozoic. Russian Geology and Geophysics 53 (3), 221-233. http://dx.doi.org/10.1016/j.rgg.2012.02.001.

Trifonov V.G., Soboleva O.V., Trifonov R.V., Vostrikov G.A., 2002. Recent geodynamics of the Alpine-Himalayan collision belt. GEOS, Moscow, 225 p. (in Russian) [Трифонов В.Г., Соболева О.В., Трифонов Р.В., Востриков Г.А. Современная геодинамика Альпийско-Гималайского коллизионного пояса. М.: ГЕОС, 2002. 225 с.].

Tsimbarevich P.M., 1948. Rock Mechanics. Ugletekhizdat, Moscow, 184 p. (in Russian) [Цимбаревич П.М. Механика горных пород. М.: Углетехиздат, 1948. 184 с.].

Turchaninov I.A., 1982. Status and trends of research of stress fields in rocks. In: Nature and the methodology for determining the tectonic stress in the upper crust. Proceedings of All-USSR workshop "Measuring of stresses and its application in the prediction of earthquakes". Kola Branch of the USSR Academy of Sciences, Apatity, p. 5-9 (in Russian) [Турчанинов И.А. Состояния и основные направления исследований в скальных породах // Природа и методология определения тектонических напряжений в верхней части земной коры: Материаль Всесоюзной школы-семинара «Измерение напряжений и их приложение в прогнозе землетрясений». Апатиты: Кольский филиал АН СССР, 1982. С. 5-9].

Turcotte D.L., 1974. Membrane tectonics. Geophysical Journal of the Royal Astronomical Society 36 (1), 33-42. http://dx.doi.org/10.1111/j.1365-246X.1974.tb03624.x.

Tychkov S.A., Kuchai O.A., Bushenkova N.A., Bragin V.D., Kalmetieva Z.A., 2008. Current crustal deformation in the northern Tien Shan: GPS and seismological data. Russian Geology and Geophysics 49 (4), 280-290. http://dx.doi.org/10.1016/j.rgg.2007.05.006.

Vlasov A.N., Merzlyakov V.P., 2009. Averaging of Deformation and Strength Properties of Rock Mechanics. ASV, Moscow, 208 p. (in Russian) [Власов А.Н., Мерзляков В.П. Усреднение деформационных и прочностных свойств в механике скальных пород. М.: Изд-во Ассоциации строительных вузов, 2009. 208 с.].

Voigth B., 1966. Beziehugen zwischen grossen horirontalen Spannugen in Gebirgen und der Tektonik und der Abtragung. In: Proceedings of the First Congress of the International Society for Rock Mechanics. Vol. 2. Laboratório nacional de engenharia civil, Lisboa, p. 51-56.

Voigth B., St. Pierre B.H.P., 1974. Stress history and rock stress. In: Advances in rock mechanics. Proceedings of the Third Congress of the International Society for Rock Mechanics. Vol. 2. National Academy of Sciences, Denver, p. 580-582.

Yudakhin F.N., 1978. Comparative geophysical characteristics of some intermountain basins of Northern Kyrgyzstan. In: K.E. Kalmurzaev (Ed.), Geological and geophysical features and seismicity of the territory of Kyrgyzstan. Ilim Frunze. P. 51-62 (in Russian) [Юдахин Ф.Н. Сравнительная геофизическая характеристика некоторых межгорных впадин Северной Киргизии // Геолого-геофизические особенности и сейсмичность территории Киргизии / Ред. К.Е. Калмурзаев. Фрунзе: Илим, 1978. С. 51-62].

Zhalkovskii N.D., Kuchai O.A., Muchnaya V.I., 1995. Seismicity and some characteristics of the stress state of the Earth's crust in the Altai-Sayan region. Geologiya i Geofizika (Russian Geology and Geophysics) 36 (10), 20-30 (in Russian) [Жалковский Н.Д., Кучай О.А., Мучная В.И. Сейсмичность и некоторые характеристики напряженного состояния земной коры Алтае-Саянской области // Геология и геофизика. 1995. Т. 36. № 10. С. 20-30].

Zubovich A.V., Beisenbaev R.T., Syaochan V., Yunfen Z., Kuzikov S.I., Mosienko O.I., Nusipov E.N., Shchelochkov G.G., Shcherba Y.G., 2004. Recent Kinematics of the Tarim - Tien Shan - Altai Region of Central Asia from GPS Measurements. Izvestiya, Physics of the Solid Earth 40 (9), 725-734. 
Yu.L. Rebetsky: On the specific state of crustal stresses...

Zubovich A.V., Makarov V.I., Kuzikov S.I., Mosienko O.I., Shchelochkov G.G., 2007. Intracontinental mountain building in Central Asia as inferred from satellite geodetic data. Geotectonics 41 (1), 13-25. http://dx.doi.org/10.1134/ S0016852107010037.

Zubovich A.V., Trapeznikov Y.A., Bragin V.D., Mosienko O.I., Shchelochkov G.G., Rybin A.K., Batalev V.Y., 2001. Deformation field, Earth's crust deep structure, and spatial seismicity distribution in the Tien Shan. Geologiya i Geofizika (Russian Geology and Geophysics) 42 (10), 1634-1640.

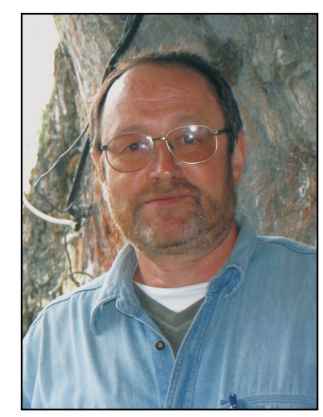

Ребецкий Юрий Леонидович, докт. физ.-мат. наук, зав. лабораторией тектонофизики им. М.В. Гзовского

Институт физики Земли им. О.Ю. Шмидта РАН

123995, ГСП-5, Москва Д-242, ул. Большая Грузинская, 10, Россия

Тел.: 84992549350; \ email: reb@ifz.ru

Rebetsky, Yuri L., Doctor of Physics and Mathematics, Head of M.V. Gzovsky Laboratory of Tectonophysics O.Yu. Schmidt Institute of Physics of the Earth, RAS

10 Bol'shaya Gruzinskaya street, Moscow D-242 123995, GSP-5, Russia

Tel.: 84992549350; $₫$ email: reb@ifz.ru 